\title{
IMPLEMENTASI PEMBELAJARAN PENDIDIKAN KEWARGANEGARAAN DALAM PEMBENTUKAN PERILAKU SISWA BERWARGA NEGARA YANG BAIK DI SD JUARA KELURAHAN BACIRO KECAMATAN GONDOKUSUMAN KOTA YOGYAKARTA TAHUN PELAJARAN 2016
}

\author{
Oleh: \\ La Haris \\ NIM: 1140101498 \\ Universitas Cokroaminoto Yogyakarta
}

\begin{abstract}
Abstrak
Jenis penelitian yang digunakan adalah deskriftif kualitatif. Dalam penelitian ini yang menjadi informan/responden adalah 2 orang yang mewakili Sekolah Dasar Juara yang diwakili oleh Kepala Sekolah dan Guru kelas, selanjutnya perwakilan dari masyarakat sekitar sebanyak 2 orang, dan kepala dinas pendidikan Kota Yogyakrta. Objek penelitian ini adalah Sekolah Dasar Juara. Teknik pengumpulan data menggunakan wawancara. Yang digali dalam wawancara, yakni seputar pelaksanaan pembelajaran Pendidikan Kewarganegaraan dan pembentukan perilaku anak dengan pelajaran PKn. Teknik analisis data dalam penelitian ini adalah analisis deskriptif kualitatif.

Hasil penelitian menunjukkan bahwa Implementasi pembelajaran PKn di Sekolah Dasar Juara Yogyakarta dalam pembentukan perilaku siswa sudah lsesuai dengan apa yang telah diharapkan seperti adanya siswa-siswa yang berkepribadian baik yang digembleng oleh Sekolah Juara. Hal ini dapat dilihat dari indikator berikut: (a) Usaha Sekolah Dasar Juara dalam mengkombinasi pembelajaran antara pelajaran agama dengan PKn. Seperti pelatihan bela negara berupa upacara bendera dan peringatan hari-hari besar Agama dan hari-hari besar Pahlawan Nasional yang dilakukan diluar jam belajar di sekolah, (b) Adanya komitmen yang tinggi dari pihak Sekolah Juara dalam menjalankan dan mengevaluasi pelaksanaan pembelajaran PKn sehingga mudah difahami: (c) Dalam pelaksanaan proses belajar mengajar hendaknya Sekolah Dasar Juara memprioritaskan pelajaran PKn sebagaima mata pelajaran yang mampu memberikan motivasi dan edukasi tersendiri bagi siswa untuk mengenal pandangan hidup bermasyarakat dan bernegara. (d) Untuk kebutuhan pembentukan karakteranak pihak Sekolah Dasar Juara seyogyanya mempersiapkan tenaga konseling.
\end{abstract}

Kata Kunci: Pendidikan Kewarganegaraan, Pembentukan Perilaku Siswa dan SD Juara

\section{PENDAHULUAN}

Pendidikan di Indonesia di harapkan dapat mempersiapkan peserta didik menjadi warga Negara yang memiliki komitmen yang kuat dan konsisten untuk mempertahankan Negara kesatuan Republik Indonesia. Mata pelajaran pendidikan kewarganegaraan adalah mata pelajaran yang memfokuskan pada pembentukan warga Negara yang memahami dan mampuh melaksanakan hal-hal dan kewajiban untuk menjadi warga Negara Indonesia yang cerdas, terampil, dan berkarakter yang yang di amanatkan oleh pancasila dan Undang-Undang Dasar 1945 (BSNP, 2005: 38). 
Pancasila sebagai pandangan hidup sekaligus dasar Negara dalam konteks ke Indonesiaan bukanlah pilihan yang tak mendasar. Konsep tentang Pancasila sebagai sumber dari segala sumber yang menjadi rujukan dalam segala hal sudah dilakukan sejak era sebelum kemerdekaan hingga saat ini, dengan berbagai dinamikanya. Perdebatan soal konsep tersebut untuk masuk dalam kurikulum menjadi hal yang unik dan menarik tentunya, meskipun dalam istilah yang berbeda. Pada tahun 1950 setelah Bangsa ini merebut Kemerdekaanya, yang dikenal dilingkup pendidikan adalah Civics. Yang ketika itu hanya ada dua sumber (buku) yang bisa dijadikan pegangan dalam proses pembelajaran, yakni Indische Burgerschapkunde yang ditulis oleh P. Tromp dan Rech en Plicht (Indische Burgerschapkunde voor iedereen) karangan J. B Vortman. (Bambang Daoerso, 1999: 8-9).

Kedua buku tersebut berlainan isinya atau materi maupun tinjauanya. Dari buku Indische Burgerschapkunde P. Tromp, yang dibahas seputar hal-hal yang berkaitan dengan masyarakat pribumi, perngaruh Barat, Bidang sosial, ekonomi, hukum, ketata Negaraan, dan kebudayaan, masalah pertanian, masalah perburuhan, masalah kaum menengah dalam industry dan perdagangan, masalah kewanitaan, ketatanegaraan Hindia Belanda maupun pertumbuhanya dengan terbentuknya dewan rakyat (Volksraad), hukum dan pelaksanaanya, masalah pendidikan, masalah kesehatan masyarakat, masalah pajak, tentara dan angkatan laut. Sementara dalam buku J. B Vortman yang dibicarakan, yakni: "Badan pribadi yang mengutarakan masyarakat dimana kita hidup dari lahir sampai kedewasaanya, pernikahan dan keluarga serta setelah badan pribadi itu tiada, masalah besik dari objek hukum dimana dibicarakan antara lain: Eigendom Eropah dan hak-hak atas tanah, hak-hak agraris atas tanah (masalah kedaulatan raja terhadap kewajiban-kewajiban warga Negara dalam pemerintahan Hindia Belanda yang membicarakan antara lain: sejarah pemerintahan hindia Belanda, masalah Perundang-undangan, sejarah alat pembayaran dan kesejahteraan)". (Bambang Daoerso, 1999: 8-9).

Akan tetapi yang penting untuk dicatat bahwa pelajaran yang berkaitan dengan penjelasan di atas dimasa awal kemerdekaan belum dijalankan secara merata (keseluruhan sekolah) dan pelaksanaanya masih sebatas doktrin (perlunya jiwa patriotism) atau perlunya menjadi warga Negara yang baik (good citizenship) dan belum dijalankan secara ilmiah. Ketika itu istilah yang popular digunakan untuk pelajaran yang berkaitan dengan hal ini adalah "Ilmu Kewarganegaraan" sebagai mata pelajaran dan belum menggunakan bahasa Indonesia. Setelah tahun 1955 baru ada buku kewarganegaraan yang berbahasa Indonesia yang berjudul "Inti Pengetahuan Kewarganegara" yang secara subtantif isi buku tersebut adalah untuk membangkitkan dan memelihara keinsyafan dan kesadaran bahwa warga Negara 
Indonesia itu mempunyai tanggung jawab terhadap diri sendiri, terhadap masyarakat, terhadap Negara (good citizenship). Isi buku pelajaran tersebut adalah (1) Indonesia Tanah Airku; (2) Indonesia Raya; (3) Bendera dan Lambang Negara; (4) Warga Negara beserta hak dan kewajibanya; (5) Ketatanegaraan; (6) Keuangan Negara; (7) Pajak, (8) Perekonomian termasuk Koperasi. (Noor Syam, 1986: 53)

Seiring dengan berjalanya waktu istilah "Kewarganegaraan" di media 1961 diganti dengan istilah "Kewargaan Negara" atas prakarsa Dr. Saharjo., SH. Adapun maksud penggantian tersebut adalah untuk disesuaikan dengan pasal 26 ayat 2 UUD 1945 yang berbunyi: "Penduduk adalah warga Negara Indonesia dan orang asing yang bertempat tinggal di Indonesia", dimana undang-undang ini menitik beratkan pada warga, yang mengandung pengertian akan hak dan kewajibannya terhadap Negara. Warga artinya anggota, jadi warganegara berarti anggota dari suatu Negara.

Dengan demikian ada perbedaan antara hak dan kewajiban antara warganegara dengan orang asing. Namun istilah "Kewargaan Negara" baru dipakai secara resmi pada tahun 1967 sesuai instruksi Direktur Jenderal pendidikan dasar No. 31 tahun 1967 tanggal 28 Juni 1967. (Bambang Daoerso, 1999: 10)

Selanjutnya pada tahun 1975 berganti kembali dengan Pendidikan Moral Pancasila (PMP) yang sekarang kembali lagi seperti semula dimata pelajaran Pendidikan Kewarganegaraan atau Pendidikan Kewarganagaraan diganti dengan Pendidikan Moral Pancasila dan mata pelajaran ini mempunyai dasar konstitusi, yaitu: "Ketetapan yang mengatakan untuk mencapai cita-cita tersebut maka kurikulum disemua tingkat pendidikan, mulai dari taman kanak-kanak sampai perguruan tinggi baik negeri maupun swasta harus berisikan pendidikan moral pancasila dan unsur-unsur yang cukup untuk meneruskan jiwa dan nilai-nilai UUD 1945 kepada generasi muda". (Bambang Daoerso, 1999: 11)

Dari relevansi asumsi yang mengatakan uniknya metamorfosa dari konsep moral Pancasila ketika harus masuk dalam kurikulum pendidikan, artinya konsep ini bukan konsep instan, melainkan sebuah konsep utuh dan konprehensip melewati proses yang panjang dan dinamika akademik yang memadai. Dari esensi yang matang itulah sehingga konsep tersebut representatif untuk menjadi landasan filsafat yang dapat dijadikan dasar dan yang menuju suatu masyarakat yang adil dan makmur. Sementara asumsi yang menjurus pada menariknya metamorfosa konsep Pancasila ini adalah adanya ketegasan istilah bahwa "Pendidikan Moral Pancasila" menyangkut usaha-usaha dan proses pembinaan warga Negara yang baik dan terdidik serta bermoral pancasila. Hal ini jelas bahwa pendidikan moral pancasila harus bersumber dari pancasila. Selain itu ada ketegasan pula bahwa yang diajarkan terhadap warga 
Negara itu, moralnya. Artinya, meskipun pendidikan moral pancasila bukan pendidikan etika. Namun dalam pengertian moral ini adalah sikap dan tingkah laku dalam rangka penghayatan dan pengamalan pancasila. Karena itu, untuk urusan apa pun dalam konteks ke-Indonesiaan harus sesuai dengan pancasila, (Notonagoro, 1997:51).

Inilah doktrin utama yang berhasil ditanamkan kepada seluruh warga Negara sejak kemerdekaan hingga sekarang. Sekali lagi bahwa konsep Pancasila sebagai sumber dari segala sumber hukum adalah menyangkut banyak hal, mulai dari urusan politik, hukum dan sosial budaya. Mengingat konsep Pancasila mempunyai kedalaman makna dan nilai-nilai yang universal, maka tidak mengherankan pula yang menafsirkan konsep tersebut juga beragam sudut pandang dalam memaknai Pancasila itu sendiri. Dalam sebuah diskusi Ilmiah di Universitas Gajah Mada, mencuat pandangan dari Senat Universitas Gajah Mada yang mengatakan bahwa: "Pancasila bukanlah suatu konsep politis, meskipun didalamnya juga mengandung sifat politis. Namun dalam konsepnya hakekat bukan mengenai politik, akan tetapi suatu asas pandangan dunia, pandangan hidup dan saksama di atas hasil pengetahuan atau pengalaman hidup yang luas". (buah hasil perenungan jiwa yang dalam, buah hasil penelaahan cipta yang teratur Notonagoro, 1993:3)

Maka dari itu, untuk memperoleh pengertian tentang cara dan bentuk pelaksanaan serta penggunaan Pendidikan Kewarganegaraan diperlukan perabot dan persiapan sebelumnya dan selanjutnya. Maksudnya, seberapa dapat belajar dalam hal kehidupan, ilmu, teori, filsafat, dan segala sesuatu yang mengenai Negara, hukum, masyarakat dan dunia, mengenai manusia dalam hakekatnya, jiwanya, akal rasa dan kehendaknya, watak perbuatanya serta pendidikan dalam berbagai lapangan hidup, sosial, politik, ekonomi, adat-istiadat, kebudayaan dan keagamaan. Semua itu bermanfaat guna memperoleh pengertian tentang penyelesaian masalah-masalah hidup yang akhirnya tertuju kepada kebahagiaan kemanusiaan dan dunia.

Penjelasan diatas memberikan penegasan bahwa konsep tentang Pendidikan Kewarganegaraan merupakan sumber utama dalam menata perikehidupan warga Negara dan sebagai pondasi dalam perjalanan Bangsa dan Negara Indonesia. Maka ketika aparat Negara menyalagunakan wewenangya sebagai abdi Negara maka itu bertentangan dengan doktrin pendidikan kewarganegaraan khususnya pada nilai Pancasila. Konsep yang mengacu pada nilai-nilai Pancasila sebagaimana penjelasan diatas sepatutnya menjadi napas dalam pelaksanaan pendidikan terutama penentuan kurikulum mulai pendidikan dasar sampai tingkat pendidikan menengah atas.

Fenomena seperti inilah yang merupakan bukti kegagalan pelaksanaan pendidikan dalam melembagakan nilai-nilai Pancasila di setiap sekolah-sekolah. Sekolah yang 
merupakan bagian dari ruang strategis untuk melembagakan ilmu pengetahuan termasuk halhal yang berkaitan dengan nilai-nilai Pancasila seharusnya lebih kreatif mencari format baru dalam membumikan ilmu pengetahuan sehingga generasi yang dilahirkan dari proses pelaksanaan pendidikan menjadi generasi yang benar-benar handal di bidangnya.

Salah satu bukti kongkrit sekolah dikatakan berhasil melembagakan nilai-nilai Pancasila dan nilai-nilai kesusilaan adalah: "Ketika sekolah mampu mendidik dan melatih anak-anak didiknya untuk tidak sekedar trampil melainkan juga harus mampu menempatkan diri mereka ditengah-tengah masyarakat sebagai generasi yang berperilaku baik dan layak untuk diteladani. Ciri generasi yang berkepribadian seperti diatas, yakni bisa dilihat dari sopan santun yang dimiliki anak tersebut, sikap rela berkorban untuk kepentingan bersama termasuk kepentingan bela Negara (cinta tanah air). Jika ciri-ciri ini melekat dalam diri seseorang, maka orang tersebut layak disebut sebagai seseorang yang berkepribadian baik dan layak untuk diteladani. (Mar'at, 1981:73)

Tidak ada cara lain untuk menjadi pribadi sebagaimana tergambar dari penjelasan di atas selain keinginan kuat untuk belajar. Hal ini sejalan dengan apa yang dikonsepsi oleh Winkel (1999:16), yang menjelaskan hubungan antara "belajar" dengan "perkembangan" dan "pendidikan" yang orientasinya membentuk kepribadian anak. Perkembangan lanjut Wingkel dapat diartikan sebagai proses berlangsungnya perubahan-perubahan dalam diri seseorang yang membawa penyempurnaan dalam kepribadianya.

\section{KAJIAN TEORI}

\section{A. Pengertian Pendidikan Kewarganegaraan}

Secara konsepsional antara pendidikan kewarganegaraan dengan cabang ilmu lain mempunyai kesamaan, yang membedakan keduanya hanya pada sisi konten saja. Pendidikan kewarganegaraan adalah pendidikan yang mengkaji dan membahas tentang pemerintahan, konstitusi, lembaga-lembaga demokrasi, rule of law, HAM, hak dan kewajiban warganegara serta proses demokrasi. (Abdul Rozaki, 2012: 57)

Beberapa pengertian Pendidikan Kewarganegaraan menurut para ahli Zamroni dalam Aprilia: "Pendidikan kewarganegaraan adalah pendidikan demokrasi yang bertujuan untuk mempersiapkan warga masyarakat berpikir kritis dan bertindak demokratis, (http://aprilia180490.wordpress.com/2010/03/09/makalah-pendidikan-kewarganegaraan/, diakses 21 mei 2015).”

Sedangkan pengertian Pendidikan Kewarganegaraan menurut Merphin Panjaitan (1990: 75) yang mengatakan Pendidikan Kewarganegaraan adalah pendidikan demokrasi yang 
bertujuan untuk mendidik generasi muda menjadi warganegara yang demokratis dan partisipatif melalui suatu pendidikan yang dialogial.

Definisi yang sama juga disampaikan oleh Sobirin Malian, yang mengatakan bahwa: "Pendidikan Kewarganegaraan (civics), adalah konsep pendidikan yang berhakikat juga sebagai pendidikan untuk mengenali dan menghayati hak-hak warganegara yang asasi (civil right) diacarakan dengan harapan agar setiap peserta didik pada akhirnya akan dapat menyadari hak-haknya yang asasi, yang perlindunganya dijamin oleh UU Negara. Lebih lanjut Sobirin Malian menjelaskan bahwa pendidikan kewarganegaraan ini tidak hanya sebatas menyadari hak-haknya sendiri, civic dan human right education ini diharapkan pula akan dapat membangkitkan empatik dikalangan para peserta didik, ialah kesadaran bahwa orang-orang lain sebagai sesama warga atau sesama manusia itu adalah sesungguhnya juga penyandang hak yang harus pula ia hormati”. (Sobirin Malian, dkk. 2013: 02).

Jadi merujuk pada beberapa pengertian Pendidikan Kewarganegaraan sebagaimana yang diungkapkan para ahli di atas, maka Pendidikan Kewarganegaraan adalah suatu proses yang dilakukan oleh lembaga pendidikan, dimana seseorang mempelajari orientasi, sikap dan perilaku politik sehingga yang bersangkutan memiliki political knowledge, awareness, attitude, political efficiency dan political participation serta kemampuan mengambil keputusan politik secara rasional" mengenai hubungan antara warganegara dengan negara, hubungan antara warganegara dengan warganegara, dan Pendidikan Pendahuluan Bela Negara agar menjadi warganegara yang dapat diandalkan oleh bangsa dan negara.

Tujuan Pendidikan Kewarganegaraan menurut Sumarsono (2001: 04) adalah untuk menumbuhkan wawasan dan kesadaran bernegara, sikap serta perilaku yang cinta tanah air dan bersendikan kebudayaan Bangsa, wawasan nusantara, serta ketahanan nasional dalam diri para mahasiswa calon Sarjana/ Ilmuwan warga Negara kesatuan Republik Indonesia yang sedang mengkaji dan akan menguasai IPTEK dan Seni. Pendidikan Kewarganegaraan lanjut Sumarsono secara terperinsip dapat dibagi dalam dua tujuan, yakni sebagai berikut:

\section{Tujuan Umum}

Memberikan pengetahuan dan kemampuan dasar kepada mahasiswa atau siswa mengenai hubungan antara warganegara dengan negara, hubungan antara warganegara dengan warganegara, dan Pendidikan Pendahuluan Bela Negara agar menjadi warganegara yang dapat diandalkan oleh bangsa dan negar, (Sumarsono. 2001:05-06). 


\section{Tujuan Khusus}

Agar mahasiswa memahami dan melaksanakan hak dan kewajiban secara santun, jujur dan demokratis serta ikhlas sebagai Warganegara Republik Indonesia yang terdidik dan bertanggung jawab, adalah sebagai berikut:

a. Agar mahasiswa menguasai dan memahami berbagai masalah dasar dalam kehidupan bermasyarakat, berbangsa dan bernegara, serta dapat mengatasi dengan pemikiran kritis dan bertanggung jawab yang berlandaskan Pancasila, Wawasan Nusantara dan Ketahanan Nasional.

b. Agar mahasiswa memiliki sikap perilaku sesuai nilai-nilai kejuangan, cinta tanah air, rela berkorban bagi Nusa dan Bangsa, (Sumarsono, 2001: 09).

Sedangkan tujuan Pendidikan Kewarganegaraan menurut Oloparulian, dibagi dalam dua bagian sebagai berikut: Secara umum, Tujuan Pendidikan kewarganegaraan harus ajeg dan mendukung keberhasilan pencapaian Pendidikan Nasional, yaitu "Mencerdaskan kehidupan bangsa yang mengembangkan manusia Indonesia seutuhnya. Yaitu manusia yang beriman dan bertakwa kepada Tuhan Yang Maha Esa dan berbudi pekerti yang luhur, memiliki kemampuan pengetahuann dan keterampilan, kesehatan jasmani, dan rohani, kepribadian mantap dan mandiri serta rasa tanggung jawab kemasyarakatan dan kebangsaan. Serta mewujudkan Kepribadian masyarakat yang demokratis". Secara khusus, Tujuan Pendidikan Kewarganegaraan yaitu: "Membina moral yang diharapkan diwujudkan dalam kehidupan sehari-hari yaitu perilaku yang memancarkan iman dan takwa terhadap Tuhan Yang Maha Esa dalam masyarakat yang terdiri dari berbagai golongan agama, perilaku yang bersifat kemanusiaan yang adil dan beradab, perilaku yang mendukung kerakyatan yang mengutamakan kepentingan bersama di atas kepentingan perseorangan dan golongan sehingga perbedaan pemikiran pendapat ataupun kepentingan diatasi melalui musyawarah mufakat, serta perilaku yang mendukung upaya untuk mewujudkan keadilan sosial seluruh rakyat Indonesia”. ( $\quad$ http://Oloparulian.blogspot.com/2013/02/tujuan-dan-fungsi pendidikan.html, diakses 22 Mei 2015).

Sebagaimana diuraikan dalam latar belakang permasalahan diatas, bahwa salah satu konten yang hendak digali pada Pendidikan Kewarganegaraan adalah mengkaji kelembagaan Negara dan hak asasi manusia, maka disini akan dijelaskan konteks hak asasi manusia berdasarkan Konstitusi Negara Kesatuan Republik Indonesia, yakni penjelasan bahwa hak asasi manusia tidak dapat dipisahkan dengan pandangan filosofis tentang manusia yang melatarbelakanginya. Menurut Pancasila hakikat manusia adalah tersusun atas jiwa dan raga, kedudukan kodrat sebagai makhluk Tuhan dan mahluk pribadi, adapun sifat kodratnya 
sebagai makhluk Individu dan makhluk social. Dalam pengertian ini lah, maka hak-hak asasi manusia tidak dapat dipisahkan dengan hakikat kodrat manusia tersebut. Konsekuensinya dalam realisasinya, maka hak-hak asasi manusia senantiasa memiliki hubungan yang korelatif dengan wajib asasi manusia karena sifat kodrat manuisa sebagai individu dan mahluk social. (Kaelan, 1998: 176)

Dalam rentang Sejarah berdirinya Bangsa Indonesia dalam kenyataanya secara resmi deklarasi Bangsa Indonesia telah lebih dulu dirumuskan dari pada deklarasi Universal hak asasi manusia PBB, karena pembukaan UUD 1945 dan pasal-pasal nya disyahkan tanggal 18 Agustus 1945, adapun deklarasi PBB pada tahun 1948. Hal ini merupakan fakta bahwa dunia telah mengetahui, bangsa Indonesia sebelum tercapainya pernyataan hak-hak asasi sedunia PBB telah mengangkat hak asasi manusia dan melindunginya dalam kehidupan Negara yang tertuang dalam UUD 1945. Hal ini juga telah ditekankan oleh para pendiri Negara misalnya pernyataan Muhammad Hatta dalam sidang BPUPKI sebagai beriku: "Walaupun yang dibentuk itu Negara kekeluargaan, tetapi masih perlu ditetapkan beberapa hak dari warga Negara, agar jangan sampai timbul Negara kekuasaan (machtsstaat atau Negara penindas)". (Kaelan, 1998: 178)

B. Landasan Hukum Pendidikan Kewarganegaraan

Beberapa landasan hukum Pendidikan kewarganegaraan antara lain sebagai berikut:

1. UUD 1945;

2. Pembukaan UUD 1945, Alinea kedua dan keempat (cita-cita, tujuan dan aspirasi Bangsa Indonesia tentang kemerdekaanya);

3. Pasal 27 (1), kesamaan kedudukan Warganegara di dalam hukum dan pemerintahan;

4. Pasal 27 (3), hak dan kewajiban Warganegara dalam upaya bela Negara;

5. Pasal 30 (1), hak dan kewajiban Warganegara dalam usaha pertahanan dan keamanan Negara;

6. Pasal 31 (1), hak Warganegara mendapatkan pendidikan;

7. UU Nomor 20 Tahun 2003 tentang Sistem Pendidikan Nasional;

8. Surat Keputusan Dirjen Dikti Nomor 43/ DIKTI/ Kep./ 2006 tentang Rambu-rambu Pelaksanaan Kelompok Pengembangan Kepribadian di Perguruan Tinggi.

\section{Pengertian Nilai dalam Materi PKn}

Pengertian nilai (value), menurut Dictionary dalam M. Daryono, dkk (2008: 34), nilai adalah harga atau kualitas sesuatu. Artinya, sesuatu dianggap memiliki nilai apabila sesuatu tersebut secara instrinsik memang berharga. Disini, nilai difungsikan untuk mengarahkan, mengendalikan, dan menentukan kelakuan seseorang, karena nilai dijadikan standar perilaku. 
Pendidikan nilai, lanjut Daryono adalah pendidikan yang mensosialisasikan dan menginternalisasikan nilai-nilai dalam diri siswa. Sementara nilai dalam Pendidikan kewarganegaraan menurut Sa'adun Akbar, dkk. 2003: 53) adalah merupakan hal yang melekat pada mata pelajaran yang berfungsi sebagai pendidikan nilai karena mensosialisasikan dan menginternalisasikan nila-nilai pancasila atau budaya bangsa melalui pembelajaran yang di lakukan dalam lingkup sekolah.

Dalam hidup bermasyarakat, berbangsa, maupun bernegara, nilai pancasila merupakan standar hidup bangsa yang berideologi pancasila dan dianjurkan disekolah-sekolah. Secara historis, nilai pancasila digali dari puncak-puncak kebudayaan, nilai agama, dan adat istiadat bangsa Indonesia sendiri, bukan dibeli dari negara lain. Nilai ini sudah ada sejak bangsa Indonesia lahir, (M. Daryono, dkk. 2008: 75). Oleh karena itu, sudah sepantasnya jika pancasila mendapat predikat sebagai jiwa bangsa.

Berdasarkan uraian di muka dapat disimpulkan bahwa dalam pendidikan, nilai sangat penting untuk ditanamkan sejak dini karena nilai bermanfaat sebagai standar pegangan hidup.

D. Pengertian Moral dalam Materi Pendidikan Kewarganegaraan

Pengertian moral, menurut Franz Magnis Suseno (1998: 97) adalah ukuran baikburuknya seseorang, baik sebagai pribadi maupun sebagai warga masyarakat, dan warga negara. Sedangkan pendidikan moral adalah pendidikan untuk menjadikan anak manusia bermoral dan manusiawi.

Walaupun moral itu berada dalam diri individu, tetapi moral berada dalam suatu sistem yang berwujut aturan. Moral dan moralitas memiliki sedikit perbedaan, moral adalah prinsip baik-buruk sedangkan moralitas merupakan kualitas pertimbangan baik-buruk. Dengan demikian, hakekat dan makna moralitas bisa dilihat dari cara individu yang memiliki moral dalam mematuhi maupun menjalankan aturan. (Franz Magnis Suseno, 1998: 75).

Moral bertujuan membantu peserta didik untuk mengenalih nilai-nilai dan menempatkannya dalam kehidupan bermasyarakat, (http://www.mandikdasmen.depdiknas.go.id/web/rsbeng/5.html/filosofipendidikan,diakses 20 Mei 2015).

Pendidikan semacam ini semakin penting dan menempati posisi sentral karena tingkat kadar persatuan dan kesatuan terutama yang berkaitan dengan kesadaran akan nilai -nilai dalam masyrakat akhir-akhir ini cenderung semakin "Pudar". Dalam pendidikan kewarganegaraan, moral sangat penting untuk ditanamkan pada lingkungan pendidikan, karena proses pembelajarannya bertujuan untuk membentuk moral anak, yaitu moral yang sesuai dengan nilai yang sesuai dengan kehidupan di masyarakat pada umumnya. 
Berdasarkan uraian tersebut, dapat disimpulkan bahwa pengertian moral dan moralitas adalah suatu tuntutan perilaku yang baik yang dimiliki individu sebagai moralitas, yang tercermin dalam pemikiran/ konsep, sikap, dan tingkah laku.

E. Pengembangan Nilai dan Moral dalam PKn

Ada beberapa hal yang perlu diperhatikan dalam pelaksanaan pendidikan nilai antara lain sebagai berikut:

1. Wawasan moral (kesadaran moral, dan wawasan nilai moral-kemampuan mengambil pandangan orang lain, penalaran moral, mengambil keputusan, pemahaman diri sendiri.

2. Dimensi perasaan moral (kata hati atau nurani, harapan diri sendiri, merasakan diri orang lain, cinta kebaikan, kontrol diri, merasakan diri sendiri).

3. Perilaku moral (kompetensi, kemauan, kebiasaan) (Lickona, 1992).

Pendidikan nilai di Indonesia seyogyanya berpijak pada nilai-nilai keagamaan, nilai demokrasi yang ber-Ketuhanan Yang Maha Esa. Nilai sosial-kultural yang ber-Bhinneka Tunggal Ika, karena demokrasi di Indonesia adalah demokrasi yang theistik/ ber-Ketuhanan Yang MahaEsa. (https://kewarganegaraanblog.wordpress.com/2013/10/25/definisipendidikan-kewarganegaraan-menurut-ahli/, diakses 20 Mei 2015).

F. Materi PKn Untuk Kelas 1V di Sekolah Dasar Juara

Untuk kontek Sekolah Dasar Juara, khususnya dikelas 1V implementasi materi pendidikan kewarganegaraan, meliputi:

1. Memahami hak sebagai warga dalam kehidupan di Rumah, di Sekolah, dan masyarakat. Inti dari materi ini, yaitu penjelasan tentang bagaimana seorang siswa didalam lingkungan keluarganya mendapatkan perlakuan yang wajar dari keluarganya. Artinya, para siswa dipenuhi segala kebutuhanya baik yang berkaitan dengan pendidikanya, makan dan minum sehari-hari, termasuk uang jajanya. Sedangkan dilingkungan masyarakat, bagaimana seorang siswa harus mendapatkan perlindungan yang prima dari keluarga sehingga anak-anak terhindar dari segala tekanan apa pun dan lain sebagainya.

2. Melaksanakan kewajiban sebagai warga Negara dalam kehidupan sehari-hari di Rumah, di Sekolah, dan dimasyarakat. Praktis dari materi ini adalah penjelasan tentang tingkah laku seorang siswa dalam aktivitas sehari-hari. Bagaimana seorang siswa menjadi anak yang baik (berbakti kepada kedua orang tua), menghormati orang lain dan turut berpartisipasi menjaga keharmonisan keluarga. Penjelasan selanjutnya, yakni bagaimana seorang siswa dalam proses belajar-mengajar menjadi anak yang berprestasi yang kelak bisa mengharumkan nama bangsa dan keluarga tentunya. Selain itu, seorang siswa dalam kehidupana bermasyarakat, bertanggung jawab dalam menjaga hubungan baik dengan 
teman-temanya secara bijak dan berkontribusi dalam menjaga keharmonisan dalam lingkungan sekitar.

\section{G. Pembentukan Prilaku Siswa \\ 1. Pengertian perilaku}

Berbicara prilaku, sudah tentu perhatian akan mengarah pada kepribadian sesorang berikut kebiasaan yang melekat pada setiap individu. Secara teoritis konsep perilaku merupakan konsep yang luas, tetapi secara sederhana istilah perilaku mencakup karakteristik perilaku individu. Setiap individu memiliki perilaku unik yang dapat dibedakan dari individu lain, (Waluyo B, 2009: 138). Hal yang tidak mungkin apabila seseorang dapat memiliki banyak perilaku. Agar lebih memahami konsep dan pengertian tentang perilaku yang luas tersebut, marilah kita simak batasan yang telah diberikan oleh beberapa ahli berikut:

a. Roucek dan Warren, menjelaskan bahwa perilaku adalah organisasi faktor-faktor biologis, psikologis, dan sosiologis yang mendasari perilaku individu.

b. Yinger, berpendapat bahwa perilaku adalah keseluruhan perilaku dari seorang individu dengan sistem kecenderungan tertentu yang berinteraksi dengan serangkaian situasi.

c. Robert Sutherland (dkk), menganggap bahwa perilaku merupakan abstraksi individu dan kelakuannya sebagaimana halnya dengan masyarakat dan kebudayaan. Dengan demikian perilaku digambarkan sebagai hubungan saling mempengaruhi antara tiga aspek tersebut, (Waluya B, 2009: 138).

Dari penjelasan para ahli di atas, maka penulis menyimpulkan bahwa perilaku adalah keseluruhan tindak-tanduk individu yang dipengaruhi oleh berbagai macam factor seperti psikologi, biologis, kebudayaan, dan sosiologi yang terjadi secara abstrak serta saling mempengaruhi.

Ada kalanya seseorang melihat perilaku yang "membabi buta", yakni perilaku manusia yang didasarkan pada naluri, dorongan-dorongan, refleks, atau kelakuan manusia yang tidak lagi dipengaruhi dan ditentukan oleh akal dan jiwanya. Unsur-unsur akal dan jiwa yang menentukan perbedaan perilaku setiap individu merupakan susunan kepribadiaan yang meliputi sikap, kebiasaan, dan lain-lain, (Waluya B: ibid).

Hal yang berbeda disampaikan oleh Sukmadinata yang mengaitkan prilaku seperti kepribadian dengan prestasi yang diukir setiap individu. Kepribadian lanjut Sukmadinata (2005: 133) adalah sesuatu yang dimiliki atau tidak dimiliki.

Orang yang tidak berpribadi adalah orang yang lemah, mudah berubah, tidak berpendirian, ragu-ragu dalam bertindak, tidak bertanggung jawab dan sebagainya. Ada dua bentuk kepribadian menurut Sukmadinata, yaitu kepribadian yang menarik dan kepribadian 
yang membosankan. Kepribadian yang menarik atau yang subur (lot of person), mengambarkan suatu sosok yang memiliki sifat-sifat: mudah menarik simpati orang, mengesankan, berbudi pekerti, sopan santun, memberikan kesan pertama yang baik. Sedangkan kepribadian yang membosankan atau gersang (no person) menunjukan adanya sifat-sifat yang tidak disukai orang, membosankan, kurang bersemangat, tidak menarik, tidak mendalam, mudah dilupakan. Kurang lebih sama dengan pendapat diatas, definisi kepribadian juga disetir oleh Winkel, yang menyebut kepribadian sebagai kekhasan seseorang, untuk sebagian, Nampak dalam cara dia melakukan pekerjaanya, (Sukmadinata2005: 134). Seperti contoh seorang guru yang berprofesi sebagai pendidik bagi anak-anak disekolah. Secara tidak sadar, dengan kehadiranya dikelas, guru sudah memberikan pengaruh terhadap perkembangan siswa.

Kesimpulan dari berbagai definisi tersebut dapat dikatakan bahwa kepribadian sesungguhnya merupakan integrasi dari kecenderungan seseorang untuk berperasaan, bersikap, kepribadian bertindak, dan berperilaku sosial tertentu. Dengan demikian perilaku, memberi watak yang khas bagi individu dalam kehidupan sehari-hari. Kepribadian bukanlah perilaku, namun kepribadianlah yang membentuk perilaku manusia, sehingga dapat dilihat dari cara berpikir, berbicara, bertindak atau berperilaku. Kepribadian lebih berada dalam alam psikis (jiwa) seseorang yang diperlihatkan melalui perilaku. Kepribadian mencakup kebiasaan, sikap, dan sifat seseorang yang khas dan berkembang apabila berhubungan dengan orang lain.

2. Pembentukan Perilaku

Ada beberapa unsur yang paling berperan penting, ketika berbicara soal pembentukan perilaku antara lain sebagai berikut :

a. Pengetahuan

Pengetahuan individu terisi dengan fantasi, pemahaman, dan konsep yang lahir dari pengamatan dan pengalaman mengenai bermacam-macam hal yang berbeda dalam lingkungan individu tersebut. Semua itu direkam dalam otak dan diungkapkan dalam bentuk perilaku.

b. Perasaan

Perasaan adalah suatu keadaan dalam kesadaran manusia yang menghasilkan penilaian positif atau negatif terhadap sesuatu. Bentuk penilaiannya selalu bersifat subjektif karena lebih didasarkan pada pertimbangan manusiawi dari pada rasional. Perasaan mengisi penuh kesadaran manusia tiap saat dalam hidupnya.

c. Dorongan Naluri 
Dorongan Naluri adalah kemauan yang sudah merupakan naluri pada setiap manusia. Sedikitnya ada enam macam dorongan naluri menurut depdiknas, yaitu:

1) Dorongan mempertahankan hidup;

2) Dorongan untuk berinteraksi;

3) Dorongan untuk meniru;

4) Dorongan untuk berbakti;

5) Dorongan seksual;

6) Doronganakankeindahan.

(http://www.mandikdasmen.depdiknas.go.id/web/rsbeng/5.html/filosofipendidikan, diakses pada 2 Juni 2015)

3. Unsur-Unsur Pembentukan Perilaku

Brohm (1966) dalam Syamsu Yusuf (2004: 53) mengambarkan unsur-unsur pembentukan kepribadian ini kedalam reaction theory. Pada dasarnya unsur pembentukan perilaku sangat tergantung pada perubahan sikap yang didorong oleh adanya suatu objek tertentu atau aktivitas tertentu yang menjadi sasaran dalam suatu kondisi ketidak seimbangan.

Kondisi inilah yang membantu arah sikap tersebut. Misalnya, sesorang mengiginkan sebuah mobil akan tetapi keuangan tidak mengijinkanya, akhirnya ia memutuskan membeli sepeda motor. Kondisi ini secara psikologis akan menantang seseorang untuk merubah gaya hidup dan cara bertindak meskipun harus secara ekstrim berdampak pada perubahan perilaku awal/ semula. Hal ini juga sangat ditentukan oleh komponen kognisi seperti persepsi, proses belajar sosial, menentukan dalam keberhasilan untuk mengadakan asimilasi dengan lingkungan atau sebaliknya dan komponen kognisi menentukan keputusan tentang apa yang akan diambil setelah segala sesuatu diterima (accepted) atau ditolak (rejected). (Mar'at, 1981: $51)$.

Sedangkan menurut Sijabat (1991: 111) menerangkan bahwa unsur yang mendukung terbentuknya perilaku antara lain dipengaruhi oleh beberapa faktor, yaitu faktor hereditas (pembawaan) dan faktor lingkungan, seperti (fisik, sosial, kebudayaan, spiritual).

Berikut akan penulis jelaskan secara terperinci unsur pembentukan perilaku yang disebabkan oleh factor lingkungan sebagai berikut:

a. Fisik

Faktor fisik yang dipandang mempengaruhi perkembangan perilaku dalam postur tubuh (langsing, gemuk, pendek atau tinggi), kecantikan (cantik atau tidak cantik), kesehatan (sehat atau sakit-sakitan), keutuhan tubuh (utuh atau cacat) dan berfungsinya organ tubuh. 
b. Intelegensi

Tingkat intelegensi individu dapat mempengaruhi perkembangan perilakunya. Individu yang intelegensinya tinggi atau normal biasa mampu menyesuaikan diri dengan lingkunganya secara wajar, sedangkan yang rendah biasanya sering mengalami hambatan atau kendala dalam penyesuaian diri dengan lingkunganya.

c. Keluarga

Suasana atau iklim keluarga sangat penting bagi perkembangan perilaku anak. Seorang anak yang dibesarkan dalam lingkungan keluarga yang harmonis dan agamis, dalam arti orang tua memberikan curahan kasih sayang, perhatian serta bimbingan dalam kehidupan berkeluarga, maka perkembangan perilaku anak tersebut cendrung positif.

d. Kebudayaan

Setiap kelompok masyarakat (Bangsa, Ras, atau Suku Bangsa) memiliki tradisi, adat atau kebudayaan yang khas. Tradisi atau kebudayaan suatu masyarakat memberikan pengaruh setiap anggotanya, baik yang menyangkut cara berpikir (seperti cara memandang sesuatu), bersikap atau cara berperilaku. Pengaruh kebudayaan terhadap perilaku itu, dapat dilihat dari adanya perbedaan antara masyarakat modern yang budayanya relative maju (khususnya IPTEK) sedangkan masyarkat primitive yang budayanya relative seperti dalam cara makan, berpakaian, hubungan interpersonal atau cara memandang waktu. (Arifin M, 1976: 76).

Sementara unsur-unsur yang mempengaruhi pembentukan perilaku anak menurut Fenton (1956) dalam Yusuf (2004: 129) menjelaskan bahwa faktor-faktor yang menyebabkan terjadinya perubahan perilaku kedalam dua kategori yaitu:

a. Faktor lingkungan social budaya, seperti (pendidikan, rekreasi, dan partisipasi social)

b. Faktor dalam diri individu itu sendiri, seperti (tekanan emosional, identifikasi terhadap orang lain dan imitasi).

Dari pendapat di atas, dapat disimpulkan bahwa faktor-faktor yang menyebabkan terjadinya perubahan/ pembentukan perilaku meliputi lingkungan sosial, keluarga, dan teman main. Selain itu juga perubahan perilaku sedikit banyak dipengaruhi oleh faktor internal seperti kebiasaan mudah marah, salah faham dan lain-lain.

\section{H. Faktor-Faktor Pendukung Terbentuknya Prilaku Siswa}

1. Keluarga 
Rumah atau keluarga adalah tempat pendidikan pertama kali bagi seorang anak dan merupakan tempat yang paling berpengaruh terhadap pola hidup seorang anak. Anak yang hidup di tengah keluarga yang harmonis, yang selalu melakukan ketaatan kepada Allah SWT, sunnah-sunnah Rasulullah SAW ditegakkan dan terjaga dari kemunkaran, maka ia akan tumbuh menjadi anak yang taat dan pemberani. Oleh karena itu, setiap orang tua muslim harus memperhatikan kondisi rumahnya. Ciptakan suasana yang islami, tegakkan sunnah, dan hindarkan dari kemunkaran. Mohonlah pertolongan kepada Allah agar anak-anak kita menjadi anak-anak yang bertauhid, berakhlak dan beramal sesuai dengan sunnah.

Rasulullah SAW serta mengikuti jejak para salafush-shalih.

Di dalam Ihya 'Ulumuddin (1957) sebagaimana yang dikutip dari Zakiyah Daradjat (1970: 83) tentang cara melatih anak pada budi pekerti yang baik ia menyatakan: "Ketahuilah, bahwa cara melatih anak itu sangat penting dan perlu sekali. Anak adalah amanah bagi kedua orang tuanya. Hati yang suci adalah mutiara yang amat berharga, halus dan bersih dari ukiran dan gambaran. Ia menerima semua yang dipengaruhkan kepadanya".

Dari ungkapan diatas, jelas tergambar betapa besar pengaruh orang tua (institusi keluarga) dalam membentuk perilaku anak. Orang tua bisa mewarnai anaknya dengan rupa apapun, sesuai dengan yang dikehendakinya. Namun demikian ia bukanlah ujung dari adanya fitrah, bahwa manusia iu mempunyai fitrah (sifat yang dibawa sejak lahir), namun di dalam kehidupannya di dunia ini manusia dihadapkan kepada hal-hal yang datang dari luar diri (eksternal) manusia itu sendiri yang bisa mempngaruhi kecenderungan hatinya. Al-Ghazali (1957) sebagaimana yang dikutip Hawari (1997: 83) lebih jauh mengungkapkan tentang pengaruh lingkungan keluarga yang bukan hanya sebatas pada unsur manusia yang mempengaruhi, tetapi unsur makanannya pun bisa mempengaruhi pertumbuhan dan perkembangan perilaku anak. Menanggapi hal ini, beliau menyatakan bahwa anak hendaklah diawasi dari sejak awal kelahirannya, jangan diserahkan kepada wanita yang sembarangan (tidak shaleh) untuk mengasuh dan menyusuinya, anak harus diserahkan kepada wanita yang shaleh, beragama dan makan dengan makanan yang halal untuk diasuh dan disusui.

Menurut Mahjubah (1982) dalam Rifai (1992: 13) bahwa masa kanak-kanak merupakan periode yang menentukan dalam pembentukan perilaku manusia, sebab selama masa tersebut peranan keluarga bersifat mencakup segala hal. Maka dari itu orang tua bertugas mendidik anak, dan dalam proses ini agama Islam telah menegaskan 
peranan yang penting bagi para orang tua. Allah SWT berfirman: "Hai orang-orang yang beriman, peliharalah dirimu dan keluargamu dari api neraka yang bahan bakarnya adalah manusia dan batu; penjaganya malaikat-malaikat yang kasar, keras, dan tidak mendurhakai Allah terhadap apa yang diperintahkan-Nya kepada mereka dan selalu mengerjakan apa yang diperintahkan". (Q. S. At-Tahrim (66): 6)

Dalam ayat di atas Allah memerintahkan orang-orang beriman untuk mendidik keluarga dan diri mereka dengan baik, sehingga menjadi keluarga dan orang-orang bertakwa, yang merupakan bagian dari masyarakat Islam. Oleh karena itulah orang tua harus berperan dalam pendidikan, keamanan, dan pengawasan anak mereka. Menurut Surya M. (1995: 97 - 99) bahwa orang tua harus selalu mengawasi lingkungan pergaulan anak, terutama orang tua harus mampu memerhatikan teman-teman anaknya, karena anak-anak sejak berumur kurang lebih 4 tahun sudah dapat bergaul dengan orang-orang di luar lingkungan keluarganya. Dengan bergaul ini mereka bisa mengembangkan kemampuan sosial dan kebutuhan berhubungan dengan orang lain. Untuk itu orang tua wajib menaruh perhatian dengan siapa mereka bergaul. Karena teman bergaul dapat memberikan pengaruh pada kepribadian anak-anaknya. Oleh karena itu, sejak dini orang tua harus memberikan bimbingan kepada anak-anaknya, bahkan jika mungkin kepada teman bergaulnya. Sebab tidak jarang kita temukan anakanak di rumah kita di didik dengan kejujuran, berbicara dengan sopan, bertingkahlaku hormat kepada orang tuanya, tetapi setelah bergaul dengan teman-teman ternyata pulang membawa kata-kata kotor dan berbau porno sehingga orang tua sering terkejut mendengarkan kata-kata yang diucapkan anaknya di luar itu.

Maka dari itu, menurut Buchori Nasution (2005: 75) sebaiknya orang tua tidak dapat melepaskan anak begitu saja kepada lingkungan sesuka dia. Pola hidup, budaya, perilaku serta sosial kita pertaruhkan di sini. Oleh sebab itu arahkanlah kepada lingkungan yang kondusif terhadap misi pembinaan. Perhatikanlah lingkungan bermain, lingkungan sekolahnya, lingkungan pergaulannya. Menurut Imam Al-Ghazali (1968: 35) mengatakan bahwa apabila orang tua ingin pembinaan tetap harapannya, maka:

a. Kalau ingin anaknya shaleh, pergaulan anak kita harus dengan orang-orang yang berakhlak baik.

b. Kalau ingin anaknya pandai, lingkungan pergaulannya harus bersama orang-orang pandai. 
c. Kalau ingin anaknya kaya, ia juga harus memiliki lingkungan orang yang kaya (di samping lingkungan yang kurang mampu tempat membaktikan karunia yang dilebihkan Allah padanya).

Seperti yang telah dijelaskan, bahwa lingkungan rumah dan keluarga memiliki andil yang sangat besar dalam pembentukan perilaku anak. Untuk itu pastilah ada usaha yang harus dilakukan terutama oleh pihak - pihak yang terkait didalamnya sehingga mereka akan memiliki tanggung jawab dalam hal ini.

Terdapat beberapa contoh kebiasaan yang dapat dilakukan di lingkungan keluarga:

a. Membiasakan anak bangun pagi, mengatur tempat tidur dan berolahraga

b. Membiasakan anak mandi dan berpakaian bersih

c. Membiasakan anak turut membantu mengerjakan tugas - tugas rumah

d. Membiasakan anak mengatur dan memelihara barang - barang yang dimilikinya

e. Membiasakan dan mendampingi anak belajar / mengulang pejaran/ mengerjakan tugas sekolahnya

f.Membiasakan anak pamit jika keluar rumah

g. Membiasakan anak mengucap salam saat keluar dari dan pulang ke rumah

h. Menerapkan pelaksanaan ibadah sholat sendiri dan berjamaah

i. Mengadakan pengajian Alquran dan ceramah agama dalam keluarga

j. Menerapkan musyawarah dan mufakat dalam keluarga sehingga dalam diri anak akan tumbuh jiwa demokratis

k. Membiasakan anak bersikap sopan santun kepada orang tua dan tamu

1. Membiasakan anak menyantuni anak yatim dan fakir miskin, Imam Al-Ghazali (1968: 36).

Adapun kendala-kendala yang dihadapi keluarga dalam pembentukan perilaku anak sebagai berikut:

a. Tidak ada/ kurangnya keteladanan/ contoh penerapan yang diberikan oleh orang tua.

b. Orang tua atau salah satu anggota keluarga (orang dewasa) yang tidak konsisten dalam melaksanakan usaha yang sedang diterapkan

c. Kurang terpenuhinya kebutuhan anak dalam keluarga, baik secara fisik maupun psikhis sebab ada ungkapan yang menyatakan bahwa 'kepatuhan anak berbanding sama dengan kasih sayang yang diterimanya.

d. Tempat tinggal yang tidak menetap, Abu Ahmadi (1977: 75).

Sebagai aspek kepribadian, karakter merupakan cerminan dari kepribadian secara utuh dari seseorang: mentalitas, sikap dan perilaku. Pendidikan karakter 
semacam ini lebih tepat sebagai pendidikan budi pekerti. Pembelajaran tentang tatakrama, sopan santun, dan adat-istiadat, menjadikan pendidikan karakter semacam ini lebih menekankan kepada perilaku-perilaku aktual tentang bagaimana seseorang dapat disebut berkepribadian baik atau tidak baik berdasarkan norma-norma yang bersifat kontekstual dan kultural. (Winkel, 1999: 132 - 137)

Pendidikan bukan sekedar berfungsi sebagai media untuk mengembangkan kemampuan semata, melainkan juga berfungsi untuk membentuk watak dan peradaban bangsa yang bermartabat. Dari hal ini maka sebenarnya pendidikan watak (karakter) tidak bisa ditinggalkan dalam berfungsinya pendidikan. Oleh karena itu, sebagai fungsi yang melekat pada keberadaan pendidikan nasional untuk membentuk watak dan peradaban bangsa, pendidikan karakter merupakan manifestasi dari peran tersebut. Untuk itu, pendidikan karakter menjadi tugas dari semua pihak yang terlibat dalam usaha pendidikan (pendidik).

Secara umum materi tentang pendidikan karakter dijelaskan oleh Berkowitz, Battistich, dan Bier (2008: 442) yang melaporkan bahwa materi pendidikan karakter sangat luas.

Dari hasil penelitiannya dijelaskan bahwa paling tidak ada 25 variabel yang dapat dipakai sebagai materi pendidikan karakter. Namun, dari 25 variabel tersebut yang paling umum dilaporkan dan secara signifikan hanya ada 10, yaitu:

a. Perilaku seksual

b. Pengetahuan tentang karakter (Character knowledge)

c. Pemahaman tentang moral sosial

d. Ketrampilan pemecahan masalah

e. Kompetensi emosional

f.Hubungan dengan orang lain (Relationships)

g. Perasaan keterikan dengan sekolah (Attachment to school)

h. Prestasi akademis

i. Kompetensi berkomunikasi

j. Sikap kepada guru (Attitudes toward teachers). (Bier dalam Makmur, 1997: 96).

Otten (2000) menyatakan bahwa pendidikan karakter yang diintegrasikan ke dalam seluruh masyarakat sekolah sebagai suatu strategi untuk membantu mengingatkan kembali siswa untuk berhubungan dengan konflik, menjaga siswa untuk tetap selalu siaga dalam lingkungan pendidikan, dan menginvestasikan kemasyarakat untuk berpartisipasi aktif sebagai warga Negara, Otten (2000: 25). 


\section{Sekolah}

Jika dilingkungan rumah/ keluarga, anak dapat dikatakan "menerima apa adanya" dalam menerapkan sesuatu perbuatan, maka dilingkungan sekolah sesuatu hal menjadi "mutlak" adanya, sehingga kita sering mendengar anak mengatakan pada orang tuanya “ Ma, Pa, kata Bu Guru/ Pak Guru begini bukan begitu“ Ini menunjukkan bahwa pengaruh sekolah sangat besar dalam membentuk pola pikir dan karakter, serta perilaku anak, namun hal ini pun bukanlah sesuatu yang mudah tercapai tanpa ada usaha yang dilakukan. Untuk menjadi "Bapak dan Ibu" Guru seperti dalam ilustrasi diatas butuh keteladanan dan konsistensi perilaku yang patut diteladani. (http://www.pendidikankarakter.com/pentingnya-pendidikan-karakter-dalam-duniapendidikan/, diakses pada 8 Juni 2016).

Lingkungan sekolah pun besar sekali pengaruhnya terhadap pembentukan dan perkembangan pribadi anak. Menurut Al-Ghazali (1957) bukan saja orang yang tidak punya cacat budi pekertinya yang bisa dibentuk dan dikembangkan, anak yang berakhlak buruk pun bisa diubah melalui pendidikan.

Sehubungan dengan hal ini ia menunjukkan suatu cara memperbaiki akhlak anak yang buruk melalui pendidikan di Sekolah yang baik-baik sehingga tertanam dalam pikirannya kecintaan kepada orang-orang yang perna mendidiknya selama dibangku sekolah. Berikut contoh-contoh perilaku yang dapat diterapkan di Sekolah:

a. Membiasakan siswa berbudaya salam, sapa, dan senyum. Praktis dari kebiasaan seperti ini, yaitu:

1) Anak setibanya disekolah mengucapkan salam sambil salaman dan cium tangan Guru.

2) Menyapa teman, satpam, penjual dikantin atau cleaning servis di sekolah.

3) Menyapa dengan sopan kepada tamu yang datang di Sekolah.

b. Membiasakan siswa berbicara dengan bahasa yang baik dan santun.

Adapun praktik kebiasaan ini, yaitu:

1) Mendidik siswa duduk dengan sopan di kelas.

2) Mendidik siswa makan sambil duduk ditempat yang telah disediakan, tidak sambil jalan-jalan.

3) Membimbing dan membiasakan anak sholat Dhuha dan sholat Dzuhur berjamaah di sekolah.

Upaya sekolah dalam membentuk perilaku anak dalam praktiknya tidak semuda membalik telapak tangan, dalam artian secara langsung pelaksanaan ihtiar pembinaan 
perilaku anak juga mempunyai kendala yang tidak muda. Adapun kendala-kendala yang dihadapi sekolah dalam pembentukan perilaku siswa sebagai berikut:

a. Tidak ada/ kurangnya keteladanan atau contoh yang baik.

b. Guru yang tidak konsisten dalam melaksanakan aturan yang telah ditetapkan.

c. Lingkungan sekolah yang tidak kondusif untuk pembelajaran.

Individu memiliki satu ciri yang esensial, yaitu bahwa dia selalu berperilaku atau melakukan kegiatan. Individu adalah individu selama ia masih melakukan kegiatan atau berperilaku, apabila tidak maka ia bukan individu lagi. Perilaku atau kegiatan juga meliputi hal-hal yang disadari dan tidak disadari. Seperti menulis, berbicara, berpikir, mengkhayal, adalah beberapa contoh dari perilaku yang disadari, tetapi lupa, bermimpi, serta beberapa bentuk kesalahan yang tidak sengaja dapat merupakan perilaku yang tidak disadari.

Untuk mewujudkan konsep pembentukan karakter yang ideal sebagaimana penjelasan di atas, maka sekolah dituntut untuk memainkan peran dan tanggungjawabnya untuk menanamkan dan mengembangkan nilai-nilai yang baik dan membantu para siswa membentuk dan membangun karakter mereka dengan nilai-nilai yang baik. Pendidikan karakter diarahkan untuk memberikan tekanan pada nilai-nilai tertentu seperti rasa hormat, tanggung jawab, jujur, peduli, dan adil serta membantu siswa untuk memahami, memperhatikan, dan melakukan nilai-nilai tersebut dalam kehidupan mereka sendiri. Kata character berasal dari bahasa Yunani charassein, yang berarti to engrave (melukis, menggambar), seperti orang yang melukis kertas, memahat batu atau metal. Berakar dari pengertian yang seperti itu, character kemudian diartikan sebagai tanda atau ciri yang khusus, dan karenanya melahirkan satu pandangan bahwa karakter adalah pola perilaku yang bersifat individual, keadaan moral seseorang. Setelah melewati tahap anak-anak, seseorang memiliki karakter, cara yang dapat diramalkan bahwa karakter seseorang berkaitan dengan perilaku yang ada di sekitar dirinya (Kevin Ryan, 1999: 5).

3. Lingkungan Masyarakat

Manusia merupakan subjek dalam kehidupan, sebab sebagai makhluk ciptaan Tuhan dialah yang selalu melihat, bertanya, berpikir dan mempelajari segala sesuatu yang ada dalam kehidupannya. Manusia bukan hanya tertarik mempelajari apa yang ada pada lingkungannya atau sesuatu di luar dirinya tetapi juga hal-hal tentang dirinya. Dengan perkataan lain manusia ingin mengetahui keadaan manusia sendiri, manusia 
menjadi objek studi dari manusia. Adapun lingkungan yang paling berperan dalam pembentukan perilaku anak adalah lingkungan fisik dan non fisik (Sosial).

Lingkungan fisik, yaitu meliputi segala sesuatu dari molekul yang ada disekitar janin sebelum lahir sampai kepada ransangan arsitektur suatu rumah. Sedangkan liungkungan non fisik (sosial), yaitu meliputi seluruh manusia yang secara potensial mempengaruhi dan dipengaruhi oleh perkembangan individu, Syamsu Yusuf (2004: 35). Lingkungan lanjut Yusuf merupakan keseluruhan aspek atau fenomena fisik dan sosial yang mempengaruhi organisme individu.

Secara garis besar manusia terdiri dari aspek jasmani dan rohani atau fisik dan psikis. Walaupun dapat disebutkan secara terpisah, tetapi dalam kenyataannya kedua aspek itu tidak dapat dipisahkan, keduanya merupakan satu kesatuan, yaitu kesatuan jasmani-rohani atau kesatuan psiko-fisik. Memang perkataan individu berasal dari bahasa yunani "individuum" yang berarti sesuatu yang tidak dapat dipisahkan (undivided dalam bahasa inggris). Selama berstatus sebagai individu (manusia itu masih hidup) maka aspek fisik dan psikis itu membentuk satu kesatuan yang tidak dapat dipisah-pisahkan, dan akan terpisah apabila individu telah meninggal. individu atau orang yang telah meninggal adalah suatu organisme yang telah berpisah jasmani dan rohaninya, dengan demikian mereka bukan individu lagi, mereka telah berganti status menjadi mayat.

Secara esensial, lingkungan merupakan awal dari proses sosialisasi pada anak, karena dalam kehidupan sehari-hari pada nantinya anak akan berhubungan dengan dunia luar untuk proses sosialisasi baik itu dengan orang tua maupun dengan teman sebaya. Dalam hal ini lingkungan berperan penting dalam pembentukan perilaku anak. Saat usia dini, lebih mudah pembentukan karakter anak. Sebab, ia dalam hal ini adalah anak cepat menyerap perilaku dari lingkungan sekitarnya. Pada usia remaja, anak perkembangan mental berlangsung sangat cepat, karena lingkungan yang baik akan membentuk karakter yang positif dan lingkungan yang jelek akan membentuk perilaku yang negatif, Ki Gunawan (1989: 69).

Dalam lingkupnya perilaku atau kegiatan individu juga mencakup aspek kognitif, pemikiran atau penggunaan rasio: aspek afektif seperti perasaan, keinginan, kemauan, sikap dan nilai: dan aspek psikomotor yang menyangkut berbagai segi keterampilan, (Nanang Syaodiyah, 2005: 27). Jadi perilaku atau kegiatan individu itu mencakup segala pernyataan atau aktivitas hidup, baik yang disadari atau pun tidak, terlihat atau tidak terlihat, aspek kognitif, afektif dan psikomotor. Individu tidak berada dalam ruang 
hampa, ia selalu berada dalam lingkungan tertentu. Demikian halnya dengan perilaku individu, selalu berlangsung dalam interaksi dengan lingkungan. Ada beberapa pengertian tentang lingkungan dalam psikologi, yaitu lingkungan sekitar, lingkungan yang berpengaruh dan lingkungan efektif. Lingkungan sekitar atau dalam bahasa jermannya "umgebung" merupakan segala sesuatu yang ada disekitar individu, mencakup lingkungan alam, manusia, budaya, teknologi, dll. Yang ada disekitar individu.

Di samping itu yang tidak kalah pentingnya pendidikan di masyarakat. Lingkungan masyarakat juga sangat mempengaruhi terhadap karakter seseorang. Lingkungan masyarakat luas sangat mempengaruhi terhadap keberhasilan penanaman nilai-nilai etika, estetika untuk pembentukan karakter atau perilaku anak. Menurut Qurais Shihab (2010: 321), situasi kemasyarakatan dengan sistem nilai yang dianutnya, mempengaruhi sikap dan cara pandang masyarakat secara keseluruhan. Jika sistem nilai dan pandangan mereka terbatas pada kini dan di sini, maka upaya dan ambisinya terbatas pada hal yang sama. Dengan demikian, jelas bahwa pada dasarnya pendidikan baik di keluarga, sekolah maupun masyarakat sangatlah berperan penting dalam pembentukan karakter seorang anak dan bangsa.

I. Berwarga Negara Yang Baik

Salah satu ukuran untuk melihat seseorang layak disebut warga negara yang baik adalah dilihat dari sepak terjangnya sebagai warga negara yang berhasil dalam menjalankan perannya masing-masing disetiap bidang yang ditekuni dan juga harus selalu respon terhadap kuputusan-keputusan pemerintah dan selalu peduli terhadap negaranya sendiri dengan memakai prinsip demokrasi, (Herdiawanto, dkk. 2010: 35).

Tidak hanya itu saja, warga negara yang baik juga harus memiliki sikap rasa hormat dan bertanggung jawab selain itu selalu bersikap jujur, terbuka dan kritis dalam setiap apa yang dia lakukan. Ciri lain dari warga negara yang baik bisa dilihat dari bagaimana komitmenya dalam menjalankan hak dan kewajibanya sebagai warga negara. Adapun hak dan kewajiban warga negara yang baik terutama kesadaran bela negara akan terwujud dalam sikap dan perilakunya bila ia dapat merasakan bahwa konsepsi demokrasi dan hak asasi manusia sungguh-sungguh merupakan sesuatu yang paling sesuai dengan kehidupannya sehari-hari. Pembelaan negara merupakan sebuah tekad, sikap dan tindakan warga negara yang teratur, menyeluruh, terpadu dan berlanjut yang dilandasi oleh kecintaan terhadap tanah air serta kesadaran hidup berbangsa dan 
bernegara, Noviap dalam. (http://blogspot.co.id/2014/04/tema-definisi-warga-negarayang-baik.html, diakses pada 23 Juli 2016).

Warga negara yang baik seharusnya memiliki ciri-ciri taat kepada Hukum, tanggung jawab, cinta tanah air, sopan, santun dan ramah tamah. Dalam gambaran warga negara yang baik sendiri merupakan pemberdayaan warga negara optimalisasi pengembangan peranan warga negara akan menunjang proses menjadi demokrasi, jika mampu meningkatkan efektifitas masyarakat politik sehingga mampu melakukan kontrol dan menguasai negara. Itu sebabnya warga negara yang baik harus mampu membangkitnya negaranya dan menjaga nama baik bangsa dan negara.

Sedangkan pengertian warga negara yang baik menurut (Karta Sapoetra, 1993: 48) diartikan sebagai bagian dari suatu penduduk yang menjadi unsur negara. Istilah ini dahulu biasa disebut hamba atau kawula negara. Istilah warga negara lebih sesuai dengan kedudukannya sebagai orang merdeka dibandingkan dengan istilah hamba atau kawula negara, karena warga negara mengandung arti peserta, anggota atau warga dari suatu negara, yakni peserta dari suatu persekutuan yang didirikan dengan kekuatan bersama. Untuk itu, setiap warga negara mempunyai persamaan hak di hadapan hukum. Semua warga negara memiliki kepastian hak, privasi, dan tanggung jawab, (Karta Sapoetra, 1993: 46). Sejalan dengan definisi di atas, AS Hikam pun mendefinisikan bahwa warga negara yang baik merupakan terjemahan dari citizenship adalah anggota dari sebuah komunitas yang membentuk negara itu sendiri, Hikam (1999: 35). Istilah ini menurutnya lebih baik ketimbang istilah kawula negara, karena kawula negara betulbetul berarti objek yang dalam bahasa Inggris (object) berarti orang yang dimiliki dan mengabdi kepada pemiliknya.

Secara singkat, Koerniatmanto (1998: 74) mendefinisikan warga negara dengan anggota negara. Sebagai anggota negara, seorang warga negara mempunyai kedudukan yang khusus terhadap negaranya. Ia mempunyai hubungan hak dan kewajiban yang bersifat timbal balik terhadap negaranya. Dalam konteks Indonesia, istilah warga negara (sesuai dengan UUD 1945 pasal 26) dimaksudkan untuk bangsa Indonesia asli dan bangsa lain yang disahkan undang-undang sebagai warga negara. Dalam penjelasan UUD 1945 pasal 26 ini, dinyatakan bahwa orang-orang bangsa lain, misalnya orang peranakan Belanda, peranakan Cina, peranakan Arab dan lain-lain yang bertempat tinggal di Indonesia, mengakui Indonesia sebagai Tanah Airnya dan bersikap setia kepada Negara Republik Indonesia dapat menjadi warga negara. Selain itu, sesuai dengan pasal 1 UU No. 22/ 1958 dinyatakan bahwa warga negara Republik Indonesia 
adalah orang-orang yang berdasarkan perundang-undangan dan/ atau perjanjianperjanjian dan/atau peraturan-peraturan yang berlaku sejak proklamasi 17 Agustus 1945 sudah menjadi warga negara Republik Indonesia.

Terdapat beberapa unsur yang menentukan status kewarganegaraan seseorang. Ada tiga unsur yang paling dominan menentukan status kewarganegaraan seseorang menurut (Karta Sapoetra, 1993: 49) antara lain sebagai berikut:

\section{Unsur Darah Keturunan (Ius Sanguinis)}

Istilah Ius Sanguinis adalah Kewarganegaraan dari orang tua yang menurunkannya menentukan kewarganegaraan seseorang, artinya kalau orang dilahirkan dari orang tua yang berwarganegara Indonesia, ia dengan sendirinya juga warga negara Indonesia. Prinsip ini adalah prinsip asli yang telah berlaku sejak dahulu, yang diantaranya tebukti dalam sistem kesukuan, dimana anak dari anggota sesuatu suku dengan sendirinya dianggap sebagai anggota suku itu. Sekarang prinsip ini berlaku di antaranya di Inggris, Amerika, Perancis, Jepang, dan juga Indonesia.

\section{Unsur Daerah Tempat Kelahiran (Ius Soli)}

Daerah tempat seseorang dilahirkan menentukan kewarganegaraan. Misalnya, kalau orang dilahirkan di dalam daerah hukum Indonesia, ia dengan sendirinya menjadi warga negara Indonesia. Terkecuali anggota-anggota korps diplomatik dan anggota tentara asing yang masih dalam ikatan dinas. Di samping dan bersama-sama dengan prinsip ius sanguinis, prinsip ius soli ini berlaku juga di Amerika, Inggris, Perancis, dan juga Indonesia. Tetapi di Jepang, prinsip ius soli ini tidak berlaku. Karena seseorang yang tidak dapat membuktikan bahwa orang tuanya berkebangsaan Jepang, ia tidak dapat diakui sebagai warga negara Jepang.

3. Unsur Kewarganegaraan (Naturalisasi)

Walaupun tidak dapat memenuhi prinsip ius sanguinis ataupun ius soli, orang dapat juga memperoleh kewarganegaraan dengan jalan pewarganegaraan atau naturalisasi. Syarat-syarat dan prosedur pewarganegaraan ini di berbagai negara sedikit banyak dapat berlainan, menurut kebutuhan yang dibawakan oleh kondisi dan situasi negara masing-masing.

Dalam pewarganegaraan ini ada yang aktif ada pula yang pasif. Dalam pewarganegaraan aktif, seseorang dapat menggunakan hak opsi untuk memilih atau mengajukan kehendak menjadi warga negara sesuatu negara. Sedangkan dalam pewaganegaraan pasif, seseorang yang tidak mau diwarganegarakan oleh suatu negara 
atau tidak mau diberi atau dijadikan warga negara suatu negara, maka yang bersangkutan dapat menggunakan hak repudiasi, yaitu hak untuk menolak pemberian kewarganegaraan tersebut.

Membicarakan status kewarganegaraan seseorang dalam sebuah negara, maka akan dibahas beberapa persoalan yang berkenaan dengan seseorang yang dinyatakan sebagai warga negara dan bukan warga negara dalam sebuah negara. Jika diamati dan dianalisis, diantara penduduk sebuah negara, ada dantara mereka yang bukan warga negara (orang asing) di negara tersebut. Dalam hal ini, dikenal dengan apatride, bipatride dan multipatride. Apatride merupakan istilah untuk orang-orang yang tidak mempunyai status kewarganegaraan. Sedangkan bipatride merupakan istilah yang digunakan untuk orang-orang yang memiliki status kewarganegaraan rangkap atau dengan istilah lain dikenal dengan dwi-kewarganegaraan. Sementara yang dimaksud dengan multipatride adalah istilah yang digunakan untuk menyebutkan status kewarganegaraan seseorang yang memiliki 2 (dua) atau lebih status kewarganegaraan.

Kasus orang-orang yang tidak memiliki status kewarganegaraan merupakan sesuatu yang akan mempersulit orang tersebut dalam konteks menjadi penduduk pada suatu negara. Mereka akan dianggap sebagai orang asing, yang tentunya akan berlaku ketentuan-ketentuan peraturan atau perundang-undangan bagi orang asing, yang selain segala sesuatu kegiatannya akan terbatasi, juga setiap tahunnya diharuskan membayar sejumlah uang pendaftaran sebagai orang asing, Hikam (1999: 35).

Kasus kewarganegaraan dengan kelompok bipatride, dalam realitas empiriknya, merupakan kelompok status hukum yang tidak baik, karena dapat mengacaukan keadaan kependudukan di antara dua negara, kerana itulah tiap negara dalam menghadapi masalah bipatride dengan tegas mengharuskan orang-orang yang terlibat untuk secara tegas memilih salah satu di antara kedua kewarganegaraannya.

Kondisi seseorang dengan status berdwikewarganegaraan, sering terjadi pada penduduk yang tinggal di daerah perbatasan di antara dua negara. Dalam hal ini, diperlukan peraturan atau ketentuan-ketentuan yang pasti tentang perbatasan serta wilayah teritorial, sehingga penduduk di daerah itu dapat meyakinkan dirinya termasuk ke dalam kewarganegaraan mana di antara dua negara tersebut.

Untuk membangun suatu tatanan masyarakat yang demokratis dan berkeadaban, maka setiap warga negara haruslah meiliki karakter atau jiwa yang demokratis pula.

Ada beberapa karakteristik bagi warga negara yang disebut sebagai yang baik dan demokrat, menurut (Rahmah, 2000: 34) yakni antara lain sebagai berikut: 
1. Rasa Hormat Dan Tanggung Jawab

Sebagai warga negara yang demokratis, hendaknya memiliki rasa hormat terhadap sesama warga negara terutama dalam konteks adanya pluralitas masyarakat Indonesia yang terdiri dari berbagai etnis, suku, ras, keyakinan, agama, dan ideologi politik. Selain itu, sebagai warga negara yang demokrat, seseorang warga negara juga dituntut untuk turut bertanggung jawab menjaga keharmonisan hubungan antar etnis serta keteraturan dan ketertiban negara yang berdiri di atas pluralitas tersebut.

2. Bersikap Kritis

Warga negara yang demokrat hendaknya selalu bersikap kritis, baik terhadap kenyataan empiris (realitas sosial, budaya, dan politik) maupun terhadap kenyataan supra-empiris (agama, mitologi, kepercayaan). Sikap kritis juga harus ditujukan pada diri sendiri. Sikap kritis pada diri sendiri itu tentu disertai sikap kritis terhadap pendapat yang berbeda. Tentu saja sikap kritis ini harus didukung oleh sikap yang bertanggung jawab terhadap apa yang dikritisi.

3. Membuka Diskusi Dan Dialog

Perbedaan pendapat dan pandangan serta perilaku merupakan realitas empirik yang pasti terjadi di tengah komunitas warga negara, apalagi di tengah komunitas masyarakat yang plural dan multi etnik. Untuk meminimalisasi konflik yang ditimbulkan dari perbedaan tersebut, maka membuka ruang untuk berdiskusi dan berdialog merupakan salah satu solusi yang bisa digunakan. Oleh karenanya, sikap membuka diri untuk dialog dan diskusi merupakan salah satu ciri sikap warga negara yang demokrat.

4. Bersikap Terbuka

Sikap terbuka merupakan bentuk penghargaan terhadap kebebasan sesama manusia, termasuk rasa menghargai terhadap hal-hal yang tidak bisa atau baru serta pada hal-hal yang mungkin asing. Sikap terbuka yang didasarkan atas kesadaran akan pluralisme dan keterbatasan diri akan melahirkan kemampuan untuk menahan diri dan tidak secepatnya menjatuhkan penilaian dan pilihan.

5. Rasional

Bagi warga negara yang demokrat, memiliki kemampuan untuk mengambil keputusan secara bebas dan rasional adalah sesuatu hal yang harus dilakukan. Keputusan-keputusan yang diambil secara rasional akan mengantarkan sikap yang logis yang ditampilkan oleh warga negara. Sementara, sikap dan keputusan yang 
diambil secara tidak rasional akan membawa implikasi emosional dan cenderung egois. Masalah-masalah yang terjadi di lingkungan warga negara, baik persoalan politik, sosial, budaya dan sebagainya, sebaiknya dilakukan dengan keputusankeputusan yang rasional.

6. Adil

Sebagai warga negara yang demokrat, tidak ada tujuan baik yang patut diwujudkan dengan cara-cara yang tidak adil. Penggunaan cara-cara yang tidak adil adalah bentuk pelanggaran hak asasi dari orang yang diperlakukan tidak adil. Dengan semangat keadilan, maka tujuan-tujuan bersama bukanlah suatu yang didiktekan tetapi ditawarkan. Mayoritas suara bukanlah diatur tetapi diperoleh.

7. Jujur

Memilki sikap dan sifat yang jujur bagi warga negara merupakan sesuatu yang niscaya. Kejujuran merupakan kunci bagi terciptanya keselarasan dan keharmonisan hubungan antar warga negara. Sikap jujur bisa diterapkan di segala sektor, baik politik, sosial dan sebagainya. Kejujuran politik adalah bahwa kesejahteraan warga negara merupakan tujuan yang ingin dicapai, yaitu kesejahteraan dari masyarakat yang memilih para politisi. Ketidakjujuran politik adalah seorang politisi mencari keuntungan bagi partainya, karena partai itu penting bagi kedudukan.

Beberapa karakteristik warga negara yang demokrat tersebut, merupakan sikap dan sifat yang seharusnya melekat pada seorang warga negara. Hal ini akan menampilkan sosok warga negara yang otonom, yakni mampu mempengaruhi dan berpartisipasi dalam pengambilan keputusan di tingkat lokal secara mandiri. Sebagai warga negara yang otonom, ia mempunyai karakteristik lanjutan sebagai berikut:

1. Memiliki kemandirian. Mandiri berarti tidak mudah dipengaruhi atau dimobilisasi, teguh pendirian, dan bersikap kritis pada segenap keputusan publik.

2. Memiliki tanggung jawab pribadi, politik dan ekonomi sebagai warga negara, khususnya di lingkungan masyarakatnya yang terkecil seperti RT, RW, Desa, dan seterusnya. Atau juga di lingkungan sekolah dan perguruan tinggi.

3. Menghargai martabat manusia dan kehormatan pribadi. Menghargai berarti menghormati hak-hak asasi dan privasi pribadi orang per orang tanpa membedakan ras, warna kulit, golongan ataupun warga negara yang lain.

Sumber: (AgamPrasetya.Sumber: http://swordman24.blogspot.com/p/kewargl.html, diakses pada 06 Agustus 2016). 


\section{J. Kerangka Pemikiran}

Teori pembentukan kepribadian siswa menurut W.S. Wingkel (1996).

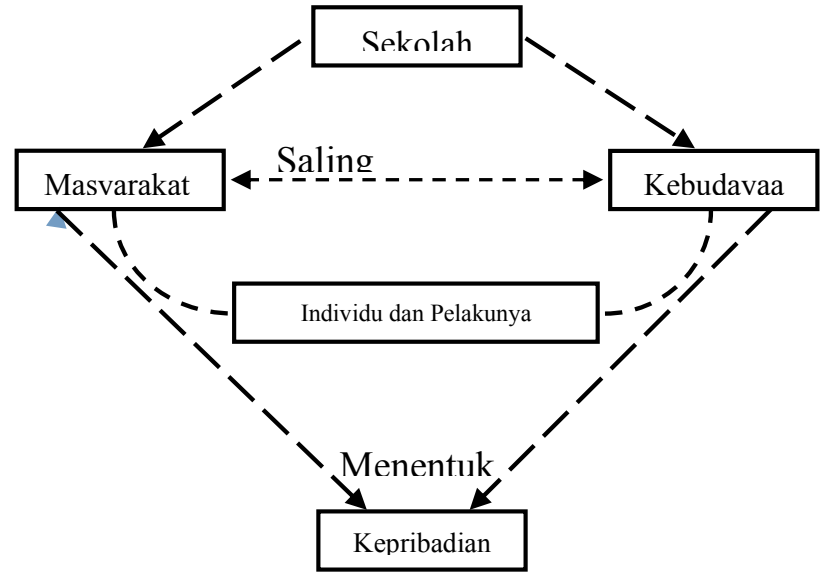

Gambar 1 Hubungan Sekolah, Masyarakat, dan Kebudayaan dalam pembentukan Kepribadian Siswa.

Gambar diatas memberikan ilustrasi tetang hubungan antara sekolah, budaya, dan masyarakat. Sekolah dilukiskan sebagai unsur yang paling dominan dalam mempengaruhi masyarakat dan kebudayaan. Dengan demikian keberadaan sekolah ditengah-tengah masyarakat sebagai pemberi warna sekaligus merupakan stimulus dalam menata segala aktivitas individu dilingkungan masyarakat.

Tanda panah putus-putus, adalah garis bujur yang merupakan symbol hubungan antara unsur satu dengan unsur yang lain. Garis putus-putus yang melingkar merupakan symbol pancaran dari dalam individu, maksudnya bahwa setiap individu akan mengalami perubahan kepribadian. Dan perubahan kepribadian setiap individu sangat dipengaruhi oleh lingkungan social (masyarakat dan kebudayaan setempat).

Karena itu. Baik buruknya lingkungan social sangat tergantung dari kematangan atau kualitas sekolah yang ada. Dengan demikian, individu akan mendapatkan kepribadian yang baik, manakalah ia berada dalam gemblengan sekolah yang berkualitas dan sokongan masyarakat dan budaya yang baik pula.

\section{METODE}

\section{A. Jenis Penelitian}

Penelitian ini menggunakan metode penelitian deskriptif dengan pendekatan kualitatif. Penelitian Tipe deskriptif kualitatif adalah penelitian yang bermaksud untuk memahami fenomena tentang apa yang dialami oleh subjek penelitian, misalnya, prilaku, persepsi, motivasi, tindakan, dan lain-lain. (Nazir, 2009: 35). 
Sedangkan menurut Whitney dalam Nazir (1988), metode deskriptif adalah pencarian fakta dengan interpretasi yang tepat. Penelitian deskriptif mempelajari masalah-masalah, tata cara yang berlaku serta situasi-situasi tertentu, termasuk tentang hubungan, kegiatan-kegiatan, sikap-sikap serta proses yang sedang berlangsung dan pengaruh-pengaruh dari suatu fenomena.

Metode Penelitian Deskriptif dalam penelitian ini digunakan untuk mempelajari gambaran secara sistematis, aktual, dan akurat mengenai fakta-fakta, sifat, dan hubungan antara fenomena-fenomena yang diteliti sehingga dapat menunjukkan bagaimana sikap responden baik pikiran, perasaan, dan tindakannya terhadap peran Pendidikan Pancasila dan Kewarganegaraan dalam membentuk Prilaku siswa. (Laxy J Moleong, 2014: 06).

Adapun dasar pokok penelitian yang digunakan adalah survey, yakni penelitian yang dilakukan untuk mencari, menemukan dan mengumpulkan data dari lapangan (informan atau responden maupun dari sumber-sumber lain yang terkait dengan data dokumen atau literatur yang relevan dengan fokus kajian) yang dianggap dapat mewakili populasi secara keseluruhan.

Menurut Burhan (2005) dalam, pendekatan kualitatif dalam penelitian sosial dimana objek peneliti dilihat memiliki keberaturan yang naturalistik, empiris, dan behavioristik, dimana semua objek peneliti harus dapat direduksi menjadi fakta yang dapat diamati, tidak terlalu mementingkan fakta sebagai makna namun mementingkan fenomena yang tampak, serta serba bebas nilai atau objektif dengan menentang habis-habisan sikap-sikap subjektif. Pendekatan kualitatif digunakan dengan pertimbangan bahwa untuk menggambarkan terkait dengan peran Pendidikan Pancasila dan Kewarganegaraan dalam membentuk prilaku siswa.

B. Waktu dan Lokasi Penelitian

1. Waktu penelitian, Penelitian ini dilakukan dari bulan Januari sampai dengan bulan April 2016.

2. Lokasi Penelitian, Penelitian ini berlokasi di Jln. Gayam No. 9, Kompleks Masjid Hidayah Yogyakarta, Kel. Baciro, Kec. Gondokusumo, Kota Yogyakarta.

C. Teknik Pengumpulan Data

Teknik pengumpulan data yang digunakan dalam penelitian ini adalah:

1. Observasi

Observasi adalah teknik pengumpulan data dengan cara melakukan pengamatan tentang kejadian atau tingkah laku yang digambarkan akan terjadi. Menurut Burhan (2005: 45).

2. Wawancara 
Wawancara adalah percakapan dengan maksud tertentu. Dimana percakapan itu dilakukan oleh dua pihak, yaitu pewawancara (interviewer) yang mengajukan pertanyaan dan terwawancara (interviewee) yang memberikan jawaban atas pertanyaan itu, (Lexy J Moleong. (2014:186).

Lebih lanjut Moleong memberi penekanan bahwa yang dilakukan dalam wawancara adalah mengkonstruksi mengenai orang, kejadian, organisasi, perasaan, motivasi, tuntutan, kepedulian dan lain-lain. Wawancara dilakukan untuk mengonstruksi kebulatan-kebulatan demikian sebagai yang dialami masa lalu, memproyeksikan kebulatan-kebulatan sebagai yang diharapkan untuk dialami pada masa yang akan datang, memferifikasi, mengubah, dan memperluas informasi yang diperoleh dari orang lain, baik manusia maupun bukan manusia (Trianggulasi).

\section{Teknik Analisis Data}

Teknik analisis data yang digunakan dalam penelitian ini adalah analisis deskriptif kualitatif. Analisis deskriptif kualitatif adalah upaya yang dilakukan dengan cara bekerja dengan data, mengorganisasikan data, memila-milah menjadi satuan yang dapat dikelola, mencari dan menemukan pola, menemukan apa yang penting dan apa yang dipelajari, dan memutuskan apa yang dapat diceritakan kepada orang lain.

Analisis data ini dilakukan dengan mengidentifikasi tema-tema utama yang ditampilkan data, menyusun kategori serta membandingkan perbedaan-perbedaan. Interpretasi peneliti nantinya akan dikompirmasikan kembali kepada responden yang disebut dengan triangulasi.

Mengingat dalam penelitian ini menggunakan tipe penelitian kualitatif, maka untuk efektifnya pendalaman atau pemahaman terhadap data yang ada, dengan demikian perlu ditetapkan prinsip Triangulasi data. Triangulasi adalah sebuah pola atau ketentuan yang ditempuh peneliti untuk mendalami atau mengetahui apa yang ingin diketahui dari pihak lain atau informan. Atau sebuah pola dengan cara mewawancarai responden atau mengkonformasi setiap informasi yang ada. (Suharsimi Arikunto, 2003: 25)

Dengan demikian untuk memenuhi pola di atas, maka penulis menetapkan responden untuk diwawancarai sebanyak 7 orang antara lain:

a. Pihak yang mewakili Sekolah Dasar juara sebanyak 2 orang, yaitu Kepala sekolah, Guru Kelas IV.

b. Pihak Dinas Pendidikan Kota Yogyakarta, yaitu Kepala Dinas Kota Yogyakarta

c. Orang Tua Murid sebanyak 1 orang.

d. Masyarakat sekitar Sekolah Dasar Juara (Kel. Baciro) 2 orang.

\section{PEMBAHASAN}




\section{A. Pembelajaran PKn di SD Juara}

Sebagai salah satu mata pelejaran yang eksistensinya sangat besar dalam membentuk kepribadian siswa, PKn selayaknya dijadikan sebagai mata ajar inti di Sekolah. Menjadikan mata pelajaran PKn sebagai mata pelajaran inti di Sekolah tidak saja sekolah akan berhasil dengan muda membentuk kepribadian atau perilaku yang baik bagi siswa siswinya. Melainkan hal itu akan menambah semangat atau rasa cinta tanah air. Selain itu mata pelajaran ini, akan dengan mudah mengantarkan siswa siswi dalam mengenal hak-hak nya sebagai warga Negara dan tujuan dari bernegara. Jika sekolah berkehendak agar murid-muridnya mempunyai pemahaman aspek bela Negara dan pentingnya hormatmenghormati antar sesame warga negara, maka tidak ada cara lain selain memantapkan pelaksanaan pembelajaran PKn di Sekolah.

Pentingnya pembelajaran PKn bagi siswa dan siswi ini secara teoritik sudah dijelaskan oleh Sobirin Malia, yang mengatakan bahwa pendidikan kewarganegaraan (civics), adalah konsep pendidikan yang berhakikat juga sebagai pendidikan untuk mengenali dan menghayati hak-hak warganegara yang asasi (civil right) diacarakan dengan harapan agar setiap peserta didik pada akhirnya akan dapat menyadari hakhaknya yang asasi, yang perlindunganya dijamin oleh UU Negara.

Penjelasan ideal ini sejalan dengan yang dipaparkan oleh Ibu (Budi Hardiastuti, S.Pd) Kepala Sekolah SD Juara saat dalam wawancara yang mengatakan bahwa: "Pelaksanaan mata pelajaran PKn di SD Juara ini kami lakukan dengan metode tematik, jadi yang mengajarkan mata pelajaran ini guru kelas. Pelajaran ini kami kemas dengan cara yang agak berbeda dengan sekolah lain mungkin kan kami masih menggunakan kurikulum 2006. Dan kami faham bahwa mata pelajaran ini kan abstrak jadi dibutuhkan taktik, keterampilan atau strategi tersendiri saat pelajaran ini diajarkan kepada siswa. Harapanya setelah pelajaran ini disampaikan paling tidak siswa bisa memahami apa sih PKn itu, dan apa muatan dalam pelajaran tersebut. Selain itu target yang ingin dicapai dalam pelajaran ini setelah guru menyampaikan mata pelajaran ini, yaitu agar setelah pelajaran ini selesai siswa telah memahami apa hak-haknya sebagai warga Negara dan kewajibanya sebagai warga Negara. Termasuk menghormati antar sesame membantu yang lain saat dikena musibah, jadi yang paling penting dari pelaksanaan PKn disekolah menurut kami ya ini”. (Wawancara bersama Kepala Sekolah SD Juara Budi Hardiastuti, S.Pd di Kantor Kepala Sekolah SD Juara pada Rabu tanggal 04 Februari 2016).

Pernyataan Ibu Kepala Sekolah SD Juara di atas jika disimak secara detail, maka terkesan ada indikasi bahwa SD Juara dalam melaksanakan PKn dalam pembelajaran 
dilakukan dengan khidmat atau sunguh-sunguh. Dan hal ini diperkuat dengan pernyataan bapak Marwoto selaku sekretaris dinas pendidikan Kota Yogyakarta dalam wawancara yang mengatakan bahwa: "untuk pelaksanaan pembelajaran PKn di sekolahsekolah dilingkup wilayah Kota Yogyakarta untuk saat ini menurut pantauan kami sudah berjalan dengan baik. Termasuk SD Juara Yogyakarta, meskipun sampai saat ini SD Juara masih menggunakan kurikulum 2006 tetapi dalam pelaksanaan pembelajaran mereka punya cara dan strategi tersendiri dan mereka menggunakan cara tematik. Dan ini sah-sah saja sekolah menggunakan metode apapun asalkan hasilnya bagus itu tidak masalah. Dan saya piker kurikulum baru 2013 tidak mempersoalkan itu, jadi asal sekolah bisa memenej dengan baik pendekatan-pendekatan pembelajaran yang mereka gunakan itu nga masalah toh kan yang paling penting itu hasilnya. Saya melihat SD juara sudah sukses menjalankan PKn ini, setiap senin mereka juga upacara meskipun lokasi sekolah mereka sangat sempit. Dan yang paling penting juga kepribadian anakanaknya menurut saya sangat baik sopan dan santun-santun itu yang menurut saya belum dimiliki sekolah lain." (Wawancara bersama bapak Marwoto sekretaris Dinas Pendidikan Kota Yogyakrta di Kantor Dinas Pendidikan Kota Yogyakarta pada tanggal 15 Februari 2016)

Penuturan kepala dinas pendidikan Kota Yogyakarta di atas menunjukan bahwa SD Juara telah mengantarkan pembelajaran PKn dengan baik dan hal ini merupakan bukti SD juara sangat memprioritaskan mata pelajaran ini sebagai mata ajar penting yang difahami sebagai mata ajar yang mampu membina mental para siswa dan siswinya. Pandangan yang sama juga dilontarkan oleh Ibu Siti, orang tua murid SD Juara dalam wawancara yang mengatakan bahwa: "Yang kami tahu pelajaran PKn di SD Juara itu dicampur dengan pelajaran lain, saya lihat buku-bukunya anak saya itu yang khusus buku PKn itu tidak ada tetapi bukan berarti mereka tidak mempelajari itu. Toh setiap Senin anak saya selalu ikut upacara bendera dan mereka juga mempelajari hal-hal yang berhubungan dengan masalah kebangsaan seperti mereka dikenalkan dengan keterampilan bela Negara kalau ada kegiatan ke Pramukaan disekolah. Pokoknya sepintas yang kami tahu sperti itu”. (Wawancara bersama Ibu Siti Orang tua Murid Sekolah Dasar Juara di Runmahnya pada tanggal 15 Februari 2016)

Penjelasan singkat dan padat yang disampaikan ibu Siti di atas merupakan kenyataan objektif yang diketahui oleh orang tua siswa dan ini sangat memberikan kesan yang berarti bagi sekolah-sekolah jika orang tua murid merasa puas dengan pelayanan sekolah yang menjadi tempat belajar anak-anaknya. Pernyataan di atas 
sedikit berbeda dengan yang dijelaskan oleh bapak Ali Hafidh salah seorang guru di SD Juara, dalam wawancara mengatakan bahwa: "Kami dalam melaksanakan pembelajaran PKn ini dalam bentuk reviw materi saja, kalau kita mau kaitkan PKn dengan pembentukan perilaku siswa, ini harus sesuai dengan bagaimana cara guru dalam menyampaikan materi pelajaran ini. Dan seharusnya ini juga harus sesuai dengan perilaku sehari-hari yang sudah dibentuk oleh orang tua". (Wawancara bersama pak Ali Hafidh salah seorang guru di SD Juara pada 21 Januari 2016 di Perpustakaan SD Juara).

Penjelasan bapak Ali Hafidh di atas tidak sedikit pun memberikan konfirmasi yang jelas dalam pelaksanaan pembelajaran PKn di SD Juara. Dan itu juga merupakan bentuk inkosistensi seorang guru dalam mematangkan kondisi siswa dalam memahami pelajaran penting di Sekolah. Penjelasan di atas sedikit berbeda dengan penjelasan bapak Suritno warga yang ada disekitar SD Juara. Bapak yang sehari-harinya sebagai Satpam ini memberikan komentar yang sedikitnya memberikan konfirmasi yang objektif, dalam wawancara mengatakan bahwa: "Pelakasanaan Pembelajaran PKn di SD juara menurut saya sudah seperti sekolah-sekolah yang ada di Yogyakarta, meskipun secara langsung saya tidak melihat langsung ya. Setiap senin mereka upacara juga layaknya sekolah lain, anak-anaknya sopan itu mas, jadi ini menurut saya berkat kemampuan guru-gurunya dalam memberikan pelajaran PKn. Saya kan melihat dari jauh ya, tetapi filing saya begitu". (Wawancara bersama Suritno warga setempat di tempat kerjanya (Pos Satpam) pada 11 Januari 2016).

Hal yang sama juga dikomentari oleh pak Heru warga setempat yang menjual disekitar SD Juara dalam wawancara yang mengatakan bahwa: "saya tidak punya anak yang sekolah di SD Juara tetapi saya tau dari teman, katanya sekolah ini bagus selain pelajaran umum juga ada pelajaran khusus. Untuk pelajaran PKn saya nga terlalu faham ditempatkan sebagai pelajaran inti atau nga itu saya belum tau, tetapi pelajaran PK nada. Setiap senin Sekolah ini saya lihat juga ada upacara, nga tau kalau hari-hari besar Nasional ikut pa nga. Yang aku suka dari sekolah ini kan mengratiskan anak-anaknya orang yang tidak mampu, jadi ini kan sangat bagus sebagai tempat anak-anak kita menuntut ilmu disitu". (Wawncara bersama bapak Heru di rumahnya timur SD Juara pada 11 Januari 2016).

Dari penjelasan beberapa responden di atas dapat ditarik kesimpulan bahwa implementasi pembelajaran PKn di SD Juara Yogyakarta sudah berjalan dengan baik sesuai dengan prosedur pembelajaran yang ada. Meskipun SD Juara masih menggunakan pendekatan yang berbeda dengan sekolah-sekolah kebanyakan namun SD 
Juara Yogyakarta mampu menunjukan ke Publik bahwa metode dalam pemberian pelajaran tidak harus terkungkung dengan satu alternative.

Memdesain beberapa alternative metode pembelajaran guna mendapatkan hasil yang baik sangat dibutuhkan dalam proses pembelajaran. Dan hal ini SD Juara telah menunjukan ini semua.

\section{B. Keterkaitan PKn Dengan Pembentukan Perilaku Siswa}

Salah satu aspek penting yang hendak dicapai dalam pelaksanaan pembelajaran PKn, yakni untuk membina kepribadian para siswa disekolah. Konsepsi ini sejalan dengan edaran dirjen dikti yang menyebut pendidikan kewarganegaraan (PKn) sebagai unsur pendidikan yang berbasis pancasila. Maka pendidikan kewarganegaraan di dukung oleh pancasila, dan oleh karena itu perlu mengembangkan pendidikan pancasila dalam rangka meningkatkan pendidikan kepribadian anak, (SK Dirjen Dikti No.43/ Dikti/ Kep./ 2006)

Sementara menurut Dahlan Faid PKn adalah sebuah konsep pelaksanaan pendidikan yang dimana di samping mengembangkan pendidikan dalama arti ilmu pengetahuan luas juga kepribadian dan yang harus di lestarikan adalah buah dari hasil perenungan bangsa sendiri yang sudah berabad-abad diamalkan baik masa jaya maupun mada derita. Masa jaya yaitu masa Sriwijaya dan Majapahit sedangkan masa derita yaitu masa, dimana Bangsa kita dalam kondisi di jajah bangsa lain, (Dahlan Thalib. 1994: 53). Penjelasan ini, memberikan pengertian bahwa faktor penting yang menjadi titik tekan pembelajaran PKn di Sekolah, yakni bagaimana pelajaran ini mampu mengantarkan para siswa untuk memahami perjalanan Bangsa serta segala bentuk dinamikanya dengan begitu rasa nasionalisme para siswi akan tumbuh dengan baik. Yang paling penting lagi bahwa pelajaran ini diharapkan mampu memantapkan rasa kekeluargaan yang tinggi sesama siswa dan penghargaan para siswa terhadap gurugurunya termasuk dengan orang lain.

Sebagaimana teori yang disampikan Notonagoro (1997) mendiskripsikan bahwa konsep pendidikan kewarganegaraan sejalan dengan Dokrin tujuan dari para pendiri bangsa dalam merumuskan NKRI sebagaimana kita ketahui bahwa salah satu cita-cita dasar kemanusiaan yang telah lama ada, sebagai bangsa yakni pengetahuan bagaimana membela dunia, yang hal ini juga merupakan cita-cita dasar kemanusiaan bangsa Indonesia yang tersimpul di dalam Pancasila. Berdasarkan kodrat manusia yang sewajarnya, maka jelas pancasila adalah asas persatuan, kesatuan, damai, kerja sama, dan hidup bersama bagi kita bangsa Indonesia. Bahwa kenyataan lingkungan pancasila 
lebih luas yang meluputi hidup bersama bangsa-bangsa dan hal itu sewajarnya mengandung sifat kodrat kemunisaan. Dan sifat kodrat kemunisaan itu adalah universal.

Lebih lanjut Kaelan menjelaskan konsep Pancasila yang dikaitkan dengan pandangan hidup bangsa Indonesia yang menyebutnya sebagai "Way of life Weltanschauung", Weldbeschouwing, Wereld en levens beschouwing, pandangan dunia, pandangan hidup, pedoman hidup, petunjuk hidup. Dalam hal ini pancasila di pergunakan sebagai petunjuk hidup sehari-hari (pancasila diamalkan dalam hidup sehari-hari). Dengan kata lain: pancasila digunakan sebagai petunjuk arah semua kegiatan atau aktivitas hidup dan kehidupan di dalam segala bidang. Ini berarti, bahwa semua tingkah laku dan tindak perbuatan setiap manusia Indonesia harus di jiwai dan merupakan pancaran dari semua sila pancasila, karena pancasila sebagai Weltanschauung selalu merupakan suatu kesatuan, tidak bisa dilepas-pisahkan satu dengan yang lain; keseluruhan sila dalam pancasila merupakan satu kesatuan organis. Pancasila yang harus dihayati ialah pancasila sebagaimana tercantum di dalam pembukaan UUD 1945.

Hal tersebut di atas sangat penting, mengingat pelaksanaan pendidikan dimaksudkan selain untuk mengembangkan pendidikan dalam arti ilmu pengetahuan luas juga kepribadian. Karena itu pelajaran PKn sangat strategis digunakan sebagai saran dalam membentuk perilaku para siswa-siswi yang ada di Sekolah. Hal ini menarik jika menyimak penjelasan Ibu Budi Kepala Sekolah SD Juara dalam wawancara yang mengatakan bahwa: "Kalau soal pembentukan perilaku siswa tidak ada lagi sarana pembelajaran yang paling tepat selain pemberian pelajaran PKn. Pengenalan terhadap cara beradaptasi dalam masyarakat itu juga bagian tak terpisahkan dari pelajaran PKn sampai pada urusan yang paling personal sekalipun juga harus sesuai dengan kaidahkaidah berinteraksi yang baik. Karena itu pelajaran ini menurut saya harus diberikan kesiswa agar mereka mampu memahami bagaimana cara bergaul, bagaimana cara hidup yang baik ditengah-tengah masyarakat". (Wawancara bersama Ibu Kepala Sekolah SD Juara (Ibu Budi) di Kantor Kepala Sekolah SD Juara pada Rabu tanggal 04 Februari 2016).

Pandangan Ibu Kepala Sekolah di atas seirama dengan yang disampaikan oleh bapak Sekretaris Dinas Pendidikan Kota Yogyakrta dalam wawancara yang mengatakan bahwa: "Menurut hemat saya, tidak ada pilihan lain bagi sekolah dalam hal menata perilaku anak-anaknya selain bagaimana membenahi cara mereka mendidik anak-anak mereka sesuai dengan nilai-nilai Pancasila. Nah, salah satunya dengan cara pemberian 
pelajaran PKn disekolah. Banyaknya kasus-kasus amoral yang terjadi di sekolah itu merupakan bukti bahwa kita selama ini telah mengeyampingkan pendidikan yang berkaitan dengan pembentukan karakter, pendidikan budi pekerti. PKn ini harus dijadikan pelajaran inti di Sekolah, pelaksana pendidikan termasuk kami harus kerja ekstra aktif dalam mengevaluasi pelaksanaan proses belajar-mengajar terutama yang berkaitan dengan PKn ini”. (Wawancara bersama Sekretaris Dinas Pendidikan Kota Yogyakarta di Kantor Dinas Pendidikan Kota Yogyakarta pada 3 Februari 2016)

Penjelasan Sekretaris Dinas di atas merupakan bentuk penegasan dari institusi pelaksana pendidikan yang memaknai pembelajaran PKn sebagai mata pelajaran penting yang diakui sangat strategis dalam membentuk perilaku siswa. Penjelasan yang sama juga disampaikan oleh Ibu Siti orang tua murid dalam wawancara yang mengatakan bahwa: "Ya Selain pelajaran agama yang bisa membentuk perilaku siswa itu hanya PKn, karena itu saya senang pada saat SD Juara mengajarkan mata pelajaran PKn secara bersamaan dengan pelajaran agama meskipun hari tentu mungkin berbeda. Anak saya juga senang mengikuti pelajaran yang ada hubunganya dengan praktik kehidupan sehari-hari karena itu PKn yang cocok dengan itu". (Wawancara bersama dengan Ibu Siti orang tua murid SD Juara pada 23 Januari 2016 dirumahnya).

Penuturan Ibu Siti di atas adalah bentuk apresiasi orang tua terhadap kelihaian Sekolah dalam mendidik anak-anak yang tentunya sesuai dengan harapan para orang tua yang mendambakan anak-anaknya bisa berperilaku baik dan berprestasi. Hal ini juga ditegaskan oleh pak Heru warga sekitar SD Juara dalam wawancara yang mengatakan bahwa: "Mungkin semua orang tua setuju dengan saya, yang mengharapkan anakanaknya bisa baik perilakunya. Jadi sekolah semestinya tidak hanya mendidik anakanak untuk jadi pintar, tetapi juga harus membentuk perilaku baik murid-muridnya. Sehingga anak-anak bisa ngerti disekolah harus ngapain dan dirumah juga harus ngapain". (Wawncara bersama bapak Heru di rumahnya timur SD Juara pada 11 Januari 2016).

Penjelasan pak Heru di atas jika disandingkan dengan penuturan Suritno warga setempat maka paling tidak semakin menguatkan penjelasan beberapa responden sebelumnya dalam wawancara yang mengatakan bahwa: "Kalau pelajaran PKn disekolah dijalankan dengan baik, saya yakin kita tidak akan melihat anak-anak saling mengganggu sesama mereka sebagaimana saat ini marak kita lihat. Banyaknya kasuskasus yang tidak layak terjadi disekolah seperti pencabulan guru terhadap muridmuridnya, kekerasan yang dilakukan guru terhadap muridnya atau bahkan perkelahian 
antara guru dengan siswanya ini kan salah satu bukti bahwa pembelajaran PKn disekolah masih belum dijalankan dengan baik".(Wawancara bersama Suritno warga setempat di tempat kerjanya (Pos Satpam) pada 11 Januari 2016).

Dari penjelasan responden di atas, dapat disimpulkan bahwa mengaitkan antara pembelajaran PKn dengan pembentukan perilaku siswa dalam proses belajar mengajar di Sekolah sangat dibutuhkan. Sebab hal itu akan memudahkan sekolah dalam mengkristalkan perilaku bijak pada siswa tidak hanya itu, tetapi jika sekolah mampu mengantarkan pembelajaran PKn dengan baik dalam proses belajar mengajar, maka hal itu akan memudahkan sekolah untuk membentuk pribadi murid yang mempunyai rasa tanggung jawab tinggi dan prinsip saling menghormati juga akan tumbuh dengan baik dalam diri siswa.

C. Faktor Pendukung dan Penghambat Pembentukan Perilaku Siswa di Sekolah

Sebagaimana Rene Dekrates memberikan tesisnya bahwa yang paling berpengaruh dari pembentukan perilaku anak adalah lingkungan. Lingkungan yang dimaksud disini adalah keluarga. Keluarga dianggap sebagai sarana yang pertama dan utama dalam membentuk kepribadian anak, melemahnya nilai-nilai dalam keluarga merupakan akibat saling pengaruh antara factor eksternal dan factor internal keluarga, dan hal ini ditandai dengan melemahnya nilai tanggung jawab dalam keluarga, tidak terpenuhinya kebutuhan akan dukungan dan perlindungan terhadap anggota keluarga, serta lunturnya moral dan kebersamaan dalam keluarga. Kekerasan terhadap anak dan eksploitasi anak untuk bekerja mencukupi kebutuhan hidup keluarga (terutama terjadi dikalangan keluarga miskin dengan melupakan hak pendidikan anak) merupakan fenomena yang cukup menggejala di perkampungan-perkampungan kumuh di perkotaan-perkotaan Indonesia akibat krisis ekonomi yang berkepanjangan.

Selain itu, faktor lain yang diakui sebagai sarana yang paling penting dalam pembentukan perilaku anak adalah sekolah sebagai tempat pengemblengan anak. Sekolah yang merupakan tempat yang diandalkan bagi public dalam memberikan pembelajaran baru bagi anak harus mampu meracik strategi khusus guna masifnya pembentukan kepribadian anak-anak didiknya. Karena itu guru sebagai tulang punggung untuk urusan pembentukan perilaku siswa ini harus ekstra aktif dalam membangun sarana edukasi yang baik kepada anak-anak didiknya. Dengan demikian guru berpegang pada nilia-nilai tertentu yang akan menampakan diri dalam pembicaraan dan tingkah laku didepan kelas, misalnya tanggung jawab dalam bertindak, kebanggaan atas hasil jeripaya sendiri, kerelaan membantu sesama dan mengorbankan 
diri, penghargaan terhadap jenis kelamin sendiri serta lawan jenis dan lain sebagainya. Disamping hal-hal yang terdapat dalam kurikulum pengajaran dan buku-buku pelajaran, guru pun menyampaikan pesan-pesan kepada siswa, yang menyangkut nilai-nilai kehidupan.

Bagaimana pandangan dan sikap guru terhadap hubungan antara wewenang penguasa dan ketaatan bawahan, antara kebebasan pribadi dan tanggung jawab pribadi, antara bekerja dan bersantai, antara konflik antar pribadi dan kerukunan antar sesama, antar kebebasan beragama, dan kerukunan agama dan lain sebagainya, akan terselip dalam cara dia mengajar dan bergaul dengan siswa. Setiap guru mempunyai pandangan tertentu mengenai baik tidaknya keteraturan hidup, kejujuran, pembauran, kekayaan, kompetisi atau persaingan, kebebasan berbicara atau mengemukakan pendapat dan seterusnya, selaras dengan peringkat nilai yang dipegang sebagai pedoman hidup. Selain itu, guru mempunyai pandangan mengenai pembagian tugas antara pria dan wanita dalam kehidupan masyarakat. Semua itu merupakan suatu program pendidikan tersendiri, yang tersembunyi dan jarang di rumuskan secara eksliplisit, namun meresapi pembicaraan dan tingkah laku guru. Oleh karena itu, Yayasan pendidikan yang ingin menciptakan suasana lingkuangan sekolah yang khas, kerap mengharuskan calon guru untuk di wawancarai lebih dahalu, supanya dapat di tentukan, apakah pandangan terhadap kehidupan dan penghanyatan dan nilai-nilai kehidupan dari calon guru sehaluan dengan pandangan dan nilai-nilai dasar yang di bina oleh Yayasan itu.

Konsep pendidikan sebagaimana penjelasan di atas sama persis dengan yang dituturkan oleh ibu kepala sekolah SD Juara saat dikonfirmasi dalam wawancara yang mengatakan bahwa: "Sebetulnya lingkungan itu sangat berperan penting dalam pembentukan perilaku anak, keluarga terutama harus bisa membuat suasana yang nyaman bagi anak. Kalau orang tua dirumah bisa berkolaborasi dengan baik terhadap sekolah saya yakin moral anak-anak kita akan baik. Saat ini kami di SD Juara sedang menjalankan misi ini sebagai bentuk tanggung jawab kami sebagai pengajar sekaligus pendidik. Kami ini kan tidak hanya disuruh ngajar tetapi juga harus mendidik, makanya guru ditekankan harus bisa menyatu dengan anak-anak didiknya sehingga dari situ akan tercipta keharmonisan antara keduanya. Kalau siswa mengangap gurunya sebagai teman, maka sudah pasti apa yang dikatakan guru akan didengarkan. Sebaliknya, jika siswa melihat gurunya sebagai musuh, maka murid tidak akan memperhatikan apa yang dikatkan gurunya. Tetapi kendala kita pastinya, lingkungan luas seperti tempat anakanak ini bermain, kan kita tidak tau ni anak kita berteman dengan siapa. Maka dari itu 
orang tua dirumah harus jelih untuk urusan ini, kita disekolah kan nga mungkin ngawasi 24 jam, ya harus ada kerja sama memang antara orang tua dengan pihak sekolah dalam menjaga anak-anak ini”. (Wawancara bersama Ibu Kepala Sekolah SD Juara (Ibu Budi Hadiastuti, S.pd) di Kantor Kepala Sekolah SD Juara pada Rabu tanggal 04 Februari 2016).

Penjelasan ibu Kepala Sekolah Di atas memberikan perspektif yang utuh tentang bagaimana strategi dalam membina perilaku anak baik diluar sekolah maupun didalam sekolah. Termasuk pembinaan yang melibatkan orang tua dan lingkungan juga berperan, penjelasan tersebut di atas juga disampaikan oleh Sekretaris Dinas Pendidikan Kota Yogyakarta yang mengatakan bahwa: "Untuk memudahkan pembentukan perilaku siswa, sekolah harus bisa mengandeng pihak lain. Selama ini memang sekolah hanya bergerak sendiri dalam membina murid-muridnya, sehingga yang terjadi sekolah kesulitan. Pada hal waktu belajar siswa disekolah kan singkat, yang banyak itu dirumah jadi ini sebetulnya yang berperan itu orang tua ini. Bagaimana orang tua sebisa mungkin memonitoring anak-anak, karena lingkungan itu sangat berpengaruh juga terhadap perkembangan anak. Syukur kalau anak bergaul sama anak-anak yang baik-baik tetapi kalau ketemua sama anak-anak yang salah urus, ya ntar anak akan besar seperti anakanak yang bergaul dengan anak-anak tadi. Nah yang kaya gini, mestinya orang tua harus cerdas meresponya dan sekolah juga harus mau bergandengan dengan orang tua dalam mendidik anak-anak muridnya. Tetapi untuk SD Juara ini saya yakin mampu mengawal keberadaan murid-muridnya. Pengkolaborasian pelajaran PKn dengan pelajaran agama ini sangat pas sekali sejauh ini saya masih mengapresiasi langkah SD satu ini”. (Wawancara bersama Sekretaris Dinas Pendidikan Kota Yogyakarta di Kantor Dinas Pendidikan Kota Yogyakarta pada 3 Februari 2016).

Penuturan Sekretaris Dinas di atas sedikit berbeda dengan yang disampaikan oleh Warga yang ada di sekitar SD Juara dalam wawancara yang mengatakan bahwa: "Untuk pembentukan perilaku siswa, saya tidak terlalu yakin sekolah mampu melakukan hal yang diharapkan. Kayanya sekolah hanya bisa mengajar tetapi tidak sungguh-sungguh mendidik anak-anak masyarakat. Banyak itu, anak-anak yang berkelahi disekolah, anak yang memeras temanya sendiri itu ada, tetapi apa ada yang menasihati atau yang melarang. Saya nga tau di SD Juara tetapi disekolah lain ada itu, ini memang bukan semua kesalahan sekolah tetapi orang tua juga, kenapa tidak memperhatikan anakanaknya”. (Wawancara bersama Suritno warga setempat di tempat kerjanya (Pos Satpam) pada 11 Januari 2016). 
Penjelasan diatas sedikitnya dikomentari oleh ibu Siti salah seorang orang tua murid di SD Juara dalam wawancara yang mengatakan bahwa: "Sepanjang yang saya fahami, SD Juara dalam proses belajar mengajar sudah melakukanya sesuai dengan standar pembelajaran yang ada. Untuk pembentukan perilaku siswa ini tidak diragukan lagi anak-anak kami sendiri sangat puas dengan didikan para guru disekolahnya, kami sebagai orang tua sangat senang melihat anak-anak kami tumbuh dengan baik kepribadianya, dan ini berkat SD Juara juga. Di SD Juara ini juga melibatkan orang tua murid dalam mendidik anak-anak, seperti pertemuan bulanan sempoa. Itu nah ini kami sangat terbantu sekali dengan program-program seperti itu". (Wawancara bersama dengan Ibu Siti orang tua murid SD Juara pada 23 Januari 2016 dirumahnya).

Penjelasan di atas sangat berbeda dengan yang disampaikan oleh Ali Hafidh salah seorang pengajar di SD Juaradalam wawancara yang mengatakan bahwa: “Apa ya, di SD Juara ini kita sudah menjalankan pembelajaran sesuai kurikulum yang ada. Kalau pelajaran PKn ini kami hanya tematik. Kemudianuntuk pembentukn perilaku siswa ini yang paling berperan orang tua sebetulnya mas. Kan waktu anak-anak di sekolah itu singkat jadi seharusnya orangtua yang berperan disini dengan waktu yang tersedia banyak itu. Kalau orang tua bisa memanfaatkan waktu yang tersedia bagi anak-anaknya, maka saya yakin anak-anak juga akan dengan muda dibentuk perilakunya, saya kira begitu mas". (Wawancara bersama pak Ali Hafidh salah seorang guru di SD Juara pada 21 Januari 2016 di Perpustakaan SD Juara).

Penjelasan tersebut di atas berbeda dengan penuturan pak Heru salah seorang warga yang keseharianya menjual disekitar SD Juara dalam wawancara yang mengatakan bahwa: "Seharusnya sekolah bersama orang tua jalan bareng untuk memikirkan bagaimana membentuk perilaku anak yang baik. Kalau tanggung jawab ini hanya diharapkan sepihak, maka akan gagal kita membentuk perilaku anak. Jadi harus ada kolaborasi yang baik antara guru dengan orang tua untuk mengawal anak-anak karena lingkungan ini kan hitam putih kita tidak tau ini anak-anak kita sedang berteman dengan siapa. Terus kita juga tidak pernah tau mereka kerjakan apa, nah mengetahui aktivitas anak-anak ini penting sekali jangan sampai kita sebagai orang tua lalai dengan ini”. (Wawncara bersama bapak Heru salah seorang warga yang tinggal disekitar SD Juara di rumahnya timur SD Juara pada 11 Januari 2016).

Setelah menyimak komentar atau penjelasan beberapa responden di atas, maka penulis menyimpulkan bahwa factor pendukung dan penghambat pembentukan perilaku siswa, yaitu lingkungan. Yang dimaksud lingkungan disini, pertama adalah keluarga. 
Kedua, lingkungan tempat anak-anak berinteraksi (lingkungan masyarakat). Dua tempat ini harus benar-benar steril, dalam artian bagaimana sekolah sebagai institusi yang diberi mandate untuk mendidik anak-anak Bangsa agar ekstra aktif dalam menjalin kerja sama.

Kerja sama bisa dilakukan dengan melibatkan orang tua murid bisa juga dengan warga masyarakat setempat sehingga monitoring terhadap interaksi para siswa akan muda terdeteksi baik siswa yang masih berada dilingkungan sekolah maupun siswa yang sudah berada diluar sekolah. Hal ini penting sebab tanggung jawab mendidik anak ini semestinya tidak saja diserahkan kepada orang tua dan sekolah, melainkan hal ini secara bersama-sama dijadikan tanggung jawab bersama warga masyarakat. Ketika warga tidak bertanggung jawab dalam hal mengawal anak-anak maka hal ini akan menjadi momentum dimana anak-anak akan dengan muda melakukan hal-hal yang tidak diinginkan seperti tindak kekerasan dan penyalagunaan narkoba dan lain sebagainya.

\section{SIMPULAN DAN SARAN}

\section{A. Simpulan}

Berdasarkan penjelasan pada bab-bab sebelumnya, maka penulis menyimpulkan bahwa Implementasi pembelajaran PKn di SD Juara Yogyakarta dilakukan dengan cara tematik atau memadukan pelajaran PKn dengan pelajaran umum yang lain seperti:

1. Kombinasi pembelajaran antara pelajaran agama dengan PKn.

2. Pemberian pelajaran bela Negara yang dilakukan diluar jam belajar di sekolah.

3. Pelajaran PKn di Sekolah Juara dilaksanakan dengan model tematik.

4. Pengenalan mata pelajaran PKn sejak dini kepada siswa-siswi dan pelibatan orang tua murid melalui pelatihan-pelatihan khusus seperti sempoa dengan maksud agar siswasiswi dengan muda didisiplinkan.

5. Adanya kolaborasi atau kerja sama yang intens antara pihak Sekolah Juara (gurugurunya) dengan orang tua murid dalam mengawal para siswa-siswi dalam memahami pelajaran PKn.

6. Menjalin kerja sama dengan lingkungan setempat untuk menjaga keberadaan para siswa-siswi di Sekolah Juara termasuk mengawal pergaulan para siswa, baik interaksi antara siswa itu sendiri maupun dengan pihak luar.

B. Saran 
Dari penjelasan pada kesimpulan di atas, maka dapat ditentukan saran atau rekomendasi dalam tulisan ini sebagai berikut:

1. Dalam pelaksanaan proses belajar mengajar hendaknya SD Juara memprioritaskan pelajaran PKn sebagai mata pelajaran yang mampu memberikan motivasi dan edukasi tersendiri bagi siswa untuk mengenal pandangan hidup bermasyarakat dan bernegara.

2. Untuk kebutuhan pembentukan karakter anak pihak SD Juara seyogyanya mempersiapkan tenaga konseling.

\section{DAFTAR PUSTAKA}

Abdul Rozaki. 2012. Mendemokratisasi Negara, Pasar, dan Masyarakat Sipil, Yogyakarta: IRE.

Abin Syamsuddin Makmur. 1997. Psikologi Kependidikan, Bandung: RemajaRosdakarya.

Abu Ahmadi. 1977. Ilmu Jiwa Anak, Semarang: Toha Putra.

Akbar Sa'dun, dkk. 2003. Laporan Penelitian Pengembangan Model Pembelajaran Terpadu, Malang: Lemlit UM.

Ali Maksurn. 2009. Pengantar Filsafat: Dari Masa Klasik Hingga Post Modernisme, Yogyakarta : Ar-Ruzz Media.

Arifin M. 1976. Psikologi dan Beberapa Aspek Kehidupan Rohania Manusia, Jakarta: Bulan Bintang.

Arikunto Suharsimi. 2013. Prosedur Penelitian: Suatu Pendekatan Praktis, Jakarta: Rineka Cipta.

Bakri Noor Ms. 2010.Pendidikan Pancasila, Yogyakara :Pustaka Pelajar.

Bambang Daroeso. 1999. Dasar Dan KonsepPendidikan Moral Pancasila, Semarang : Aneka Ilmu.

Buchori Nasution. 2005. Kiat Membangun Pendidikan Berbasiskan Keluarga, Yogyakarta : Difa Press.

Dadang Hawari. 1997. Al-Qur'an, Ilmu Kedokteran \& Kesehatan Jiwa, Yogyakarta : Dana Bhakti Prima Yasa.

Franz Magnis Suseno. 1998. Membangun Kembali Sebuah Budaya Politik Indonesia, Yogyakarta : Kanisius.

Hikam. 1999. Kedudukan Warga dan Prinsip BelaNegara Dalam Sistem Ketatanegaraan Indonesia, Yogyakarta : Resist Book. 
Isak Abdulhak. 2010. Filsafat Ilmu Pendidikan: Suatu Pengantar, Bandung: Remaja Rosdá karya.

Jalaludin \& Abdullah Idi. 2011. Filsafat Pendidikan: Manusia, Filsafat, dan pendidikan, Jakarta: Raja wali grafindo.

Johny Lumintang,dkk. 2002. Pendidikan Kewarganegaraan, Jakarta : Gramedia Pustaka Utama.

Ki Gunawan. 1989. Aktualisasi Konsep Pendidikan Ki Hadjar Dewantara Dalam Sistem Pendidikan Nasional Indonesia Di Gerbang XXI Dalam Pandangan Para Cantrik dan Mantriknya, Yogyakrta : MLPTS.

Kaelan. 1991. PancasilaYuridis Kenegaraan, Yogyakarta : Fakultas Filsafat UGM.

Koerniatmanto. 1998. Pelapisan Sosial dan Kesamaan Derajat sebagai Warga Negara, Yogyakarta : Pustaka Pelajar.

LaxyJ. Maleong. 2014. Metodologi penelitian Kualitatif, Bandung :. Remaja Rosda karya.

M. Daryono, dkk. 2008. Pengantar Pendidikan Pancasila , Jakarta: Rineka Cipta.

M. Quraish Shihab. 2010. Membumikan Kalam Di Indonesia, Yogyakarta : Pustaka Pelajar.

Mohammad Noor Syam. 1986. Filsafat pendidikan dan dasar Filsafat Pendidikan Pancasila, Surabaya: Usaha Nasional.

Mar'at. 1981. Sikap Manusia Perubahan Serta Pengukuranya, Bandung :Ghalia Indonesia.

Notonagoro. 1997. Pancasila Secara Ilmiah Populer, Jakarta: BumiAksara.

Nana Syaodih Sukmadinata. 2005. Landasan Fsikologi Proses Pendidikan, Bandung: Remaja Rosda karya.

Rifai. 1992. Tugas-Tugas Perkembangan Dalam Rangka Bimbingan dan Perawatan Anak, Bandung : Jurusan PKK IKIP Bandung.

Rahmah. 2000. Pengertian, Tujuan, Fungsi dan Unsur-Unsur Negara, Jakarta: PT. Gramedia Pustaka Utama.

Syamsul Yusuf. 2004. sikologi Perkembangan Anak \& Remaja, Bandung: Remaja Rosda karya.

Sardjonoprijo. 1982. Psikologi Kepribadian, Jakarta: Erlangga.

Surya M. 1995. Psikologi Perkembangan, Bandung : Jurusan PBB FIP IKIP Bandung.

Suseno. 1998. Pengantar Pendidikan Kewarga Negaraan :Suatu Tinjauan, Yogyakrta: Pustaka Pelajar. 
Sabirin Malia \& Suparman Marzuki. 2002. Pendidikan Kewarganegaraan \& Hak Asasi Manusia, Yogyakarta: UII Press.

Sapoetra. 1993. Kriteria dan Tanggung Jawab Warga Negara, Yogyakarta : Difa Press.

Sapoetra. 1993. Cerdas, Kritis dan Aktif Berwarga Negara, Jakarta : Erlangga.

Waluya B. 2009. Sosiologi1 :Melayani Fenomena Sosial Masyarakat Untuk Kelas X Sekolah Menengah Atas/Madrasa Aliyah. Pusat Pembukuan, Jakarta :Departemen Pendidikan Nasional.

Warji R. 1983. Program Belajar Mengajar Dengan Prinsip Belajar Tuntas (Mlastery leaning), Surabaya IDMC.

Winkel. 1999. Psikologi Pembelajaran, Jakarta : Granedia.

Zakiyah Daradjat. 1970. Ilmu Jiwa Agama, Jakarta : Bulan Bintang.

http://www.mandikdasmen.go.id./web/rsbeng,5.html/filosofipendidikan,diakses pada 20Mei 2015.

http://www.mandikdasmen.go.id./web/rsbeng,5.html/filosofi pendidikan,diakses pada 2 Juni 2015.

http:// apriliya 180490. wordpress. com /2010/03/09/ makalah -pendidikan- kewarganegaraan, diakses 21 Mei 2015.

http://belajar.sikologi.com/mengapa_perlu_adanya_pendidikan_karakter, diakses pada 06 Juni 2015.

http://belajarid.shvoong.com/humanities/philosophy/1947159/filosofipendidikan/\#xzzllFQugpaq, diaksespada 02/05/201 5.

http://oloparulian.blogspot.com/2013/02/tujuan-dan-fungsi-pendidikan.html diakses 22 Mei 2015

http ://kewarganegaraanblog.worpress.com/2013/10/25/deflnisi-pendidikan kewaranegaraan_rnenurut-ahli/, diakses 20 Mei 20 I 5.

http://blogspot.co.id/2014/04/tema-definisi-warga-negara-yang-baik.html, diakses pada 23 Juli 2016. 